\title{
Article
}

\section{Engagement of Ethnic-Minority Consumers with Electronic Word of Mouth (eWOM) on Social Media: The Pivotal Role of Intercultural Factors}

\author{
Shalom Levy ${ }^{1, * \mathbb{D}}$, Yaniv Gvili ${ }^{2}$ and Hayiel Hino ${ }^{1}$ (D) \\ 1 Department of Economics and Business Administration, Ariel University, Science Park, POB 3, \\ Ariel 40700, Israel; hayielh@ariel.ac.il \\ 2 School of Business Administration, Ono Academic College (OAC), 104 Zahal St., Kiryat Ono 55000, Israel; \\ ygvili@ono.ac.il \\ * Correspondence: shalom@ariel.ac.il
}

Citation: Levy, S.; Gvili, Y.; Hino, H. Engagement of Ethnic-Minority Consumers with Electronic Word of Mouth (eWOM) on Social Media: The Pivotal Role of Intercultural Factors. J. Theor. Appl. Electron. Commer. Res. 2021, 16, 2608-2632. https://doi.org/ $10.3390 /$ jtaer16070144

Academic Editor: Gisela Ammetller

Received: 22 August 2021

Accepted: 23 September 2021

Published: 1 October 2021

Publisher's Note: MDPI stays neutral with regard to jurisdictional claims in published maps and institutional affiliations.

Copyright: () 2021 by the authors. Licensee MDPI, Basel, Switzerland. This article is an open access article distributed under the terms and conditions of the Creative Commons Attribution (CC BY) license (https:// creativecommons.org/licenses/by/ $4.0 /)$.

\begin{abstract}
Social network sites (SNS) facilitate eWOM communication among consumers of different cultures. Building on contact theory and the theory of planned behavior, we propose a conceptual framework that integrates intercultural factors as predictors of minority consumers' engagement with eWOM communicated by and to individuals of the dominant culture on social media. A partial least squares (PLS) analysis on data collected from the Israeli-Arab minority shows that intercultural factors (i.e., acculturation, social interaction, and language proficiency) are antecedents of minority consumer engagement with eWOM. However, this relationship is mediated by consumer beliefs (attitudes, subjective norms, and perceived behavioral control) concerning this behavior, and moderated by the cultural distance between minority and dominant culture consumers. The findings help marketers plan marketing communications that engage audiences meaningfully and generate positive eWOM when targeting ethnic-cultural minorities. The current study contributes to our understanding of minority consumers' engagement with eWOM communicated by and to members of the hegemonic culture. It further contributes to consumer engagement theory and acculturation research by supporting the post-assimilationist view. The proposed model is highly valuable in light of the importance of the concept of consumer engagement in marketing research.
\end{abstract}

Keywords: social media; eWOM; engagement; culture; acculturation; minorities; commerce

\section{Introduction}

Social network sites (SNS) are used by marketers to engage ethnic minorities and generate electronic word of mouth (eWOM, see list of acronyms) [1]. With massive expansion of ethnic minorities in many countries, and intense migration to Europe and North America [2], tapping into non-mainstream-culture markets offers great business potential for growth. Procter \& Gamble has successfully pursued this strategy in 2017 when it launched "The Talk" —an extraordinary marketing campaign designed to resonate with African American consumers, and encourage a conversation among Americans in general. The campaign dealt with the racial bias facing African Americans from the viewpoint of mothers who prepare their children to cope with prejudice and racism on a daily basis [3]. Initially, online conversations about this message mainly involved African Americans and then spread to the general public [4]. The successful campaign was shared extensively on social media and became viral [5].

Nonetheless, not all ethnic marketing campaigns succeed in generating positive word of mouth among their target audiences. In 2017, Shea Moisture, a personal care brand whose customer base is mostly African American women, released a campaign to "Stop Hair Hate" on its social media channels. The campaign equated the dilemmas that many white women face with their hair-which are typically cosmetic in nature-with the 
complex hair issues of African American women that are tied to political and cultural implications. The latter group did not receive the message well: some protested on social media, and even called to boycott the brand. The company responded by pulling the campaign and posting an apology [6].

The challenges of communicating with ethnic minorities on social media necessitate better understanding of the factors that influence online ethnic marketing communication. Online social media constitutes a complicated environment for minority consumers, which poses cultural dilemmas due to conflicting potential benefits and costs. On the one hand, social media has been reported to facilitate cross-ethnic communications [1], by offering ethnic-minority consumers a simple means to connect and interact with others, and obtain informational and social support unavailable within their own ethnic community [7]. In addition, from a social-networking perspective, social media platforms help minorities expand their social ties and make new contacts outside of their ethnic group [8].

On the other hand, minority consumers participating in online social networking must overcome unique challenges, including language barriers, disapproving social norms, and conservatism [9]. Consequently, minority consumers prefer to connect on social media with others of the same ethnic group, creating spaces where they feel they belong and their voices can be heard [10]. In addition, social value, satisfying a social-interaction gratification, usually drives social media users to connect with others who are similar to themselves [11]. In this complex situation, marketers and researchers need a better understanding of ethnic minorities' motives to engage with outgroup eWOM beyond the boundaries of their own culture. This is particularly interesting under conditions of considerable cultural distancewhen the minority culture is significantly different than the majority culture in aspects such as social norms and values.

Despite the growing interest in consumer engagement our understanding of the unique aspects of minority consumers' engagement remains limited [12], specifically its drivers and outcomes [13], and the effect of intercultural factors on their inclination to engage with majority consumers. The existing literature on consumer engagement focuses on aspects such as channel attributes [14] and user characteristics [15,16], with limited attention to the role of intercultural factors.

The effects of intercultural factors on consumer behavior on social media are grounded in theoretical approaches which focus on drivers and outcomes of interactions between cultural groups, and conceptualize acculturation as pivotal to such interactions. Conceptualizing acculturation $[17,18]$ and its impact on consumers varies from simplistic-linear models $[19,20]$ to the extended post-assimilationist view which proposes more diverse modes of acculturation [21,22]. Recent empirical evidence suggests that acculturation is driven by people's behavior on social media, and that this effect may translate to offline behavior $[23,24]$.

Recent global social shifts and the growing popularity of social media, highlight the need for research on the role that intercultural factors play in intergroup eWOM communication [25] and engagement. Although marketing research has recognized consumers' differentiated motivations to engage with outgroup and in-group eWOM [26], research on intercultural drivers of engagement is limited [27]. In particular, existing research has not addressed the question of how minority eWOM behavior is affected by acculturation and related factors. With the growing popularity of social media among various minorities, this question has become increasingly interesting to researchers and practitioners alike. The present research aims to bridge this gap in the literature. Drawing upon the background presented above, the research question is as follows: how do intercultural factors influence minority consumer engagement with eWOM communication that originated from the dominant culture?

Accordingly, the objective of the current research is to bridge this gap by offering a comprehensive model of the effects of intercultural factors on minority consumers' engagement with eWOM in communication with dominant culture (DC) consumers on social media. 


\section{Literature Review and Theoretical Framework}

\subsection{Engagement with eWOM on Social Media}

Social media applications stimulate social interactions and user-generated content $[28,29]$. As they socialize online consumers generate eWOM by sharing recommendations and brand experiences with others [30]. eWOM is defined as "any positive or negative statement made by potential, actual, or former customers about a product or company, which is made available to a multitude of people and institutions via the Internet" [31] (p. 39). It is disseminated by social media across national cultures [32,33], including minority domestic cultures [24], and drives customer engagement [34].

Customer engagement is "a customer's behavioral manifestations that have a brand or firm focus, beyond purchase, resulting from motivational drivers" [34] (p. 254). Engagement is a three-dimensional concept comprised of cognitive processing, affection, and activation [15]. Engagement encompasses participation in eWOM-related activities, including receiving, initiating and sharing brand reviews, recommendations, and referrals [34]. Such activities are motivated by consumers' co-creation of value to self and others, and enhanced by consumer experience [12]. This behavioral definition of brand engagement accounts for consumer activation, and includes the time spent and effort invested by consumers in brand-related activities [15]. 'Activated' consumers may incorporate the brand into their self-concept, and sense psychological ownership of the brand as they believe that they positively influence its performance [35].

Behavioral eWOM engagement consists of various quantifiable consumer activities such as clicks, likes, shares, and comments [36]. The behavioral dimension of engagement on SNS is of particular interest because SNS facilitate immediate and virtually costless engagement opportunities [37,38], and because engagement enhances business performance by increasing revenue, profitability and competitiveness [39].

Accordingly, following TPB, and in line with past research that captured the behavioral aspect of engagement $[14,40]$, we define consumer eWOM engagement as consumers' behavioral intentions to receive and/or send eWOM. Consumer intention to receive eWOM (ITR) represents the intentional behavior of opinion seekers who engage with messages [41] they actively sought or to which they were passively exposed [40]. Consumer intention to send eWOM (ITS) represents intentional opinion-giving and opinion-sharing behaviors that characterize individuals who actively disseminate brand-related information via their social connections [41].

Engagement with eWOM, constructed as ITR and ITS, is a behavior under the control of the individual, which is driven by anticipated benefits of these acts. Furthermore, on social media it may be influenced by the social norms of consumers' social circles [42]. Thus, engagement with eWOM communication can be treated as a planned behavior. In view of this conceptualization, we employ the theory of planned behavior (TPB) to explain minority consumer behavioral intentions to engage with eWOM. While TPB is considered as one of the main theories explaining consumer attitudes and behaviors [43], meta-analyses questioned its validity [44]. Consequently, researchers proposed additional predictors that increase TPB's predictive validity of behavioral intentions [45]. This is in line with the call of Ajzen [46] and Ajzen and Fishbein to incorporate additional predictors that enhance the model's predictive power.

\subsection{Theory of Planned Behavior}

TPB asserts that an individual's social behavior is shaped by information and beliefs she possesses about it. Three beliefs operate as causal factors of behavior [46] and predict one's behavioral intentions: attitudes toward a behavior, subjective norms, and perceived behavioral control (PBC). These beliefs may vary as a function of one's socio-cultural background [47]. Accordingly, they constitute antecedents that influence minority consumers' behavioral responses to marketing communications.

An individual's attitude toward a behavior is determined by her beliefs about the attributes or value of the behavior, and her evaluation of the resulting outcome. In the 
present research, attitude is conceptualized as consumers' evaluation of product recommendations that are shared on social media by individuals from the DC. Consumers' attitudes toward marketing messages determine their proneness to consumption behaviors [48]. We, therefore, propose that attitude will affect minority behavior in a similar way.

Research has established that attitudes toward members of other cultures can affect behaviors that are associated with these individuals [49], as well as cross-cultural communications [50]. Further, intergroup interactions and intercultural relations are outcomes of feelings toward-and beliefs held regarding-members of other cultures [49]. More specifically, intercultural research suggests that immigrant consumer engagement with the DC is determined, to a large extent, by social and affective factors [51]. In particular, Askegaard et al. [22] assert that softened immigrant attitudes toward adopting symbols and behaviors associated with the DC lead to cross-cultural interactions between the two parties. Thus, minority individuals' tendency to communicate with DC members will be positively related to their attitude toward such interaction. This is especially the case with social media that facilitates cross-cultural communication [52]. Thus, the hypothesis:

Hypothesis 1 (H1). Minority consumers' intention to receive and intention to send eWOM are positively related to their attitude toward sharing eWOM with DC members.

TPB explains the influence of subjective norms on minority consumers' behavioral intentions. Subjective norms are "the perceived social pressures an individual faces when deciding to perform or not to perform the behavior in question" [46] (p. 188). Minority individuals' subjective norms may be directly related to what is deemed appropriate within her minority culture [53].

Ethnographic research on immigrant consumer behavior found that potentially conflicting ideologies and values influence immigrants' consumption [51]. Peñaloza [21] conceptualized that minorities often maintain a set of subjective norms rooted with their culture of origins which may significantly conflict with norms held by the DC, and direct their daily activities. Accordingly, in conflicting contexts immigrants' subjective norms may impede engagement with DC-originated eWOM due to pressure to avoid such behavior. In a cross-national study, Leung et al. [54] proposed that subjective norms influence people's behaviors by providing information on what behaviors are socially approved, and further demonstrated that minority individuals' subjective norms mediate the effect of culture on minorities' behavior.

Similar effects of subjective norms on behavioral intentions were reported in social media research. Subjective norms create social pressure to engage with online messages from others [55]. Since engagement with eWOM on social media involves attention to social norms within one's social circles [42], subjective norms play a critical role in shaping behaviors such as receiving and sharing product-related messages. Therefore, the following hypothesis:

Hypothesis 2 (H2). Minority consumers' intentions to receive and intentions to send eWOM are positively related to their subjective norms concerning engagement with eWOM communicated with DC individuals.

Perceived behavior control (PBC) is the individual's perceived control over behavioral execution, which is determined by her perceived capabilities to execute the behavior. Ethnic consumer research suggests that immigrants' sense of low behavioral control in social environments dominated by different cultures reduces their intention to engage in certain behaviors, including media content consumption [21]. PBC's influence on minorities' intention to engage in such behaviors is due to their desire to avoid misunderstanding and embarrassment [22].

Intercultural research suggests that intercultural differences may underlie variations in self-efficacy and familiarity with online platforms. Consequently, higher PBC of on- 
line platforms leads to higher intention to engage in online consumption behavior [56]. Therefore, the following hypothesis is proposed:

Hypothesis 3 (H3). Minority consumers' intentions to receive and intentions to send eWOM are positively related to their perceived behavioral control of engagement with eWOM communicated with DC individuals.

Based on TPB, minority consumers' engagement with eWOM is influenced by their beliefs regarding their surroundings. Such beliefs are affected by a multitude of background variables including ethnicity and culture [47]. Moreover, intercultural factors act as background factors [47,57], such that their effects on engagement are mediated by three behavioral determinants-attitude, subjective norms, and PBC. Next, we review key theoretical perspectives in intercultural research and elaborate on major predictive cross-cultural factors.

\subsection{Theoretical Perspectives in Intercultural Research}

Intercultural research is vast. Two lines of research that are most relevant to the research at hand are: (a) cultural theoretical approaches and (b) cross cultural approaches.

Cultural approaches focus on culture-related constructs and cultural dimensions of national cultural groups. Research suggests that national cultural values affect consumer engagement on social media [58], and that the nature of these effects vary across countries [32]. This research, however, overlooks potential effects of acculturation resulting from diffusion of cultural elements from DC to minority culture (MC), as well as intercultural eWOM communication.

Cross-cultural approaches are concerned with drivers and processes experienced by cultural groups and individuals upon encounters with other groups. Earlier research framed such encounters in unidimensional terms, by exploring the impact of acculturation on consumer behavior $[19,20]$. The seminal research work of Berry $[17,18]$ has laid the groundwork for the extended post-assimilationist view, which extends the gamut of interrelationship categories that minority consumers maintain with host cultures. For example, Peñaloza [21] demonstrated how Mexican minority consumption behavior in North America is mapped onto four alternative forms of acculturation. Askegaard et al. [22] empirically supported this perspective in Europe.

The majority of cross-cultural research has not been applied to the context of social media behavior. Two exceptions are Kizgin et al. [24] and Kizgin et al. [23] that conceptualized social media as an agent of acculturation, and demonstrated that certain behaviors on social media such as language preferences and social interaction drive acculturation, and offline consumer behaviors (e.g., choice, political engagement). Nevertheless, these recent studies do not examine how acculturation and cross-cultural factors affect eWOM behavior on social media.

\subsection{Cross-Cultural Factors}

Cross-cultural eWOM communications are contingent on consumers' capacity to bridge cultural gaps [59]. Marketing research suggests that consumers may be less inclined to engage in eWOM on social media than in person due to the higher perceived social risk associated with online sharing [60]. Accordingly, social risk reduces eWOM engagement [61], and this risk grows with consumer uncertainty about or unfamiliarity with others of different cultures. Additionally, consumer engagement with others goes beyond the brand, and includes communal interactions [62]. Hence, cultural disparities may hinder engagement. Therefore, we propose that consumer engagement with eWOM communicated with outgroup cultures is affected by cross-cultural factors.

The influence of cross-cultural factors on intercultural eWOM interactions is explicated by intergroup contact theory [63], which has been applied to explain intergroup interactions [64]. Contact theory posits that negative attitudes held by one group toward 
another result from lack of knowledge about that group. Under appropriate conditions, interpersonal contacts between majority and minority group members facilitate learning about outgroups. Better knowledge may lead to deeper understanding of and a more positive attitude toward outgroups, which in turn, reduce conflicts and improve intergroup relations. Interactions with outgroup members and mediated exposure to outgroup members are enablers of trustful and reduced-friction contact [65].

\subsubsection{Acculturation of Minority Consumers}

MC members often interact with the DC and its institutions in various contexts, including shopping, education, and work. During such interactions, MC members may communicate with DC members, and comply with some DC norms. These situational dynamics may lead to acculturation [66].

Acculturation is defined as "changes induced in (two cultural) systems as a result of the diffusion of cultural elements in both directions" [18] (p. 215), and is often discussed in the context of geographic migration of ethnic-cultural groups [67]. From a migrantminority population perspective, acculturation develops as its members socialize and come into contact with members of host-dominant cultures [17,51]. Native non-immigrant members of ethno-cultural minorities may experience "cultural immigration" without the confounding legal, political or geographical factors usually found in migration contexts [22]. Minorities' acculturation thus reflects the degree of identification with the DC [68], and may result in assimilation of the MC with the dominant one [66].

Intercultural research on immigrants' behavior shows that even when acculturation takes place, ethnic-cultural groups tend to remain clustered [69] while concurrently adapting to the host society [70]. Accordingly, the post-assimilationist view in consumer acculturation research recognizes that acculturation may occur take place although ethnic minorities remain distinguished from the DC [21,22,71].

As individuals become acculturated to the host society, they may adopt some values and attitudes of the host society [50,72]. Consequently, MC acculturated individuals have broader common grounds with the DC and similar consumption patterns to those of DC consumers $[21,22,51]$. Therefore, more highly acculturated MC consumers may gain greater benefits from eWOM shared on SNS, as this information is more useful and consistent with their newly adopted values and consumption preferences. The greater the anticipated benefit from eWOM, the more positive the attitude toward eWOM becomes $[47,73]$. Therefore, we hypothesize:

Hypothesis 4 (H4). MC consumers' attitudes toward engagement with eWOM communicated with DC members are positively related to MC acculturation.

Past research also supports a direct relationship between acculturation and minority consumer behavior in diverse contexts, such as choice of purchase location [74], and shopping decision making styles [75]. The underlying mechanism was proposed to be minorities' adaptation to the dominant culture, which influences minorities' choices $[76,77]$. On social media acculturation affects what information consumers use [78], which in turn shape their online shopping behavior [24]. Therefore, we hypothesize:

Hypothesis $\mathbf{5}$ (H5). Minority consumers' intentions to receive and intentions to send eWOM are positively related to their acculturation with $D C$.

\subsubsection{Language Proficiency}

DC language proficiency is MC consumers' ability to read and write in the language of the dominant culture. Intercultural research suggests that skills and competence influence people's sense of control of behavioral execution. Specifically, minority consumers' communication skills, cultural competence [79] and language proficiency [80] affect their perceived control of their interactions with outgroups [81]. Mastering the DC language enables MC social media users to understand and correctly interpret the nuances of DC 
communications [82]. Language proficiency affects MC consumers' overall media consumption patterns [83], and their perceived ability to control what they read, share and comment on, and how easily and quickly they do so [84].

On social media, host culture language proficiency facilitates minorities' cross-cultural communications [52], which further encourages their linguistic confidence [85]. Host culture language proficiency reduces language barriers and can thus improve minority behavioral control of intercultural communication over social media [86]. Social media users' multilingual proficiency fosters intercultural dialogue, collaboration, and sharing of information across cultures [82]. As text-based eWOM has increasingly become an important means of exchanging product information among consumers [87], DC language proficiency is expected to drive consumers' perceived ability to engage with eWOM shared with DC consumers. Hence:

Hypothesis 6 (H6). Minority consumers' language proficiency is positively related to their perceived behavioral control over engagement with eWOM communicated with consumers from the dominant culture.

\subsubsection{Social Interaction}

Social interactions between MC and DC consumers provide the former with opportunities to learn first-hand new behavioral repertoires that deemed appropriate and useful in DC contexts [66]. Such interactions facilitate direct contact between MC and DC consumers, and consequently fosters engagement in eWOM communication [88].

MC-DC interactions can enhance minority's sense of belongingness to the DC group [89]. Enhanced belongingness may further translate to minorities' sense of affiliation with the DC and encourage expanding their social circle to include DC individuals. Consequently, MC consumers are expected to increasingly re-interpret their subjective norms as supportive of engagement with eWOM involving DC individuals. Therefore, there is the following hypothesis:

Hypothesis 7 (H7). MC consumers' subjective norms that support engagement with eWOM communicated with DC individuals are positively related to the extent of social interactions involving $M C$ and $D C$.

\subsubsection{Cultural Distance}

Cultural distance is the extent to which cultures are different with respect to their values, norms [90], and other cultural features such as languages, and beliefs [91]. Such differences impede intergroup contacts that might otherwise promote intergroup familiarity and successful intergroup eWOM engagement of minority consumers. Typically, high culturally distant minorities maintain a more conservative orientation [92], which may in turn mitigate the effects of cross-cultural relationships.

According to Berry [17], acculturation of minority consumers is affected by cultural distance. Intercultural research shows that higher cultural distance is associated with stronger minority feelings of threat [93]. Accordingly, under high cultural distance conditions, minorities may experience threat that can hinder affective response to acculturation [92]. Further, MC groups that are culturally remote from the DC will find it harder to adopt the values and norms of the DC [94]. Under such circumstances, despite acculturation, minority consumers may not benefit significantly from eWOM shared by mainstream consumers. Consequently, acculturation will be less influential on improving consumer attitude toward eWOM. On the other hand, if cultural distance is small, acculturation can contribute considerably to minority consumers by mitigating the barriers to adopting DC's norms [66]. Hence, we hypothesize:

Hypothesis 8a (H8a). Cultural distance moderates the relationship between MC consumers' attitude toward engagement with eWOM and MC consumers' acculturation, such that MC groups that are culturally closer to the DC will show a stronger association between acculturation and 
attitude toward engagement with eWOM with DC individuals, compared to MCs that are more culturally distant from the DC.

Language proficiency alone may not be sufficient for stimulating MC consumers' perceived control of eWOM communication, as minorities' unfamiliarity with cultural symbols may interfere with their confident command of communication. Due to the interrelation between language proficiency and cultural distance [91], cultural distance is expected to moderate the relationship between language proficiency and PBC. When cultural distance is small, MC consumers can more easily use their language skills to interpret explicit and implicit messages in DC language. When the cultural distance is large, even language-proficient $\mathrm{MC}$ consumers may fall short in making sense of the subtexts and nuances of DC language messages, which reduces their perceived control of eWOM engagement. Hence:

Hypothesis $\mathbf{8 b} \mathbf{( H 8 b ) . ~ C u l t u r a l ~ d i s t a n c e ~ m o d e r a t e s ~ t h e ~ r e l a t i o n s h i p ~ b e t w e e n ~ M C ~ m e m b e r s ' ~}$ perceived behavioral control of engagement with $\mathrm{eWOM}$ and MC proficiency in DC language.

The overall conceptual framework and hypotheses are illustrated in Figure 1.

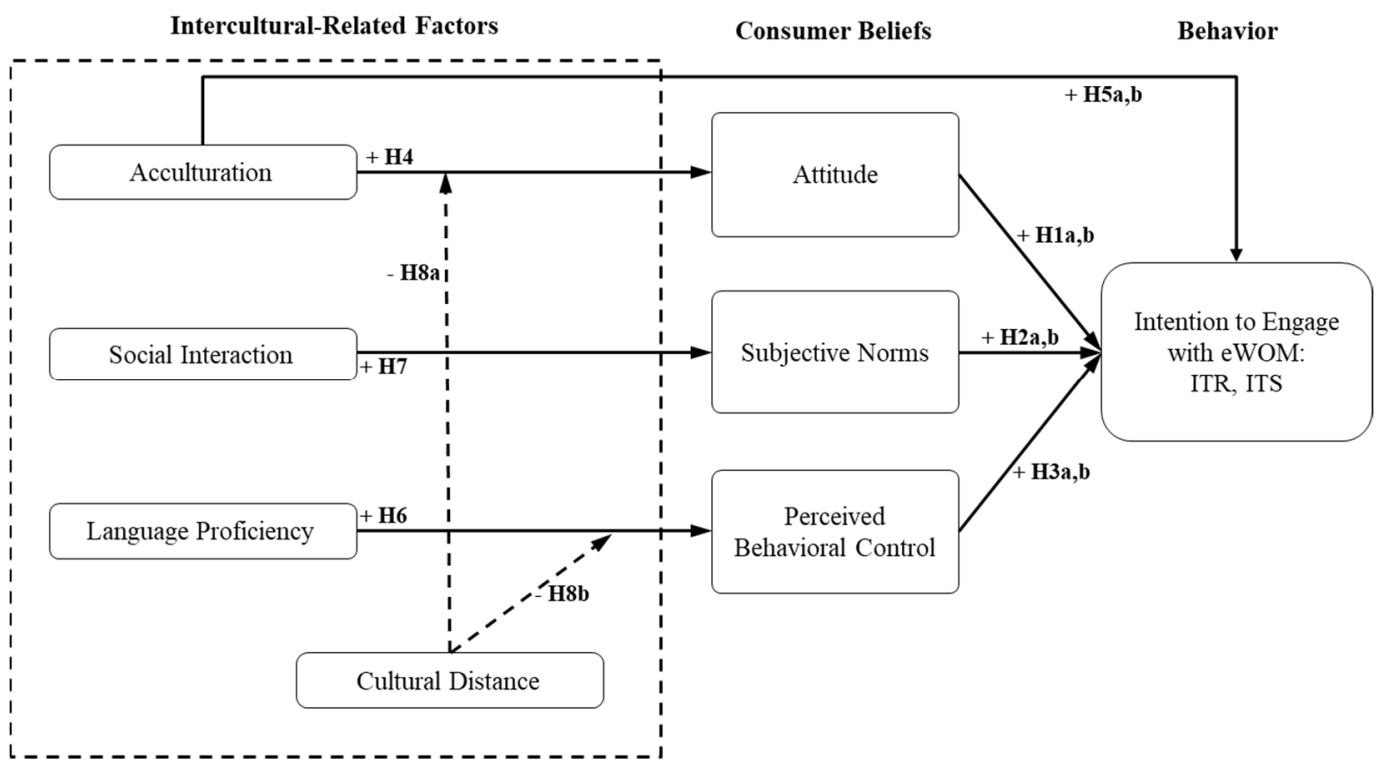

Figure 1. Conceptual Framework.

\section{Methodology}

\subsection{Sample}

Sampling for the study was conducted within the Israeli-Arab cultural community. This minority was sampled because they (a) comprise a considerable percentage of Israeli society; (b) preserve a distinct cultural orientation and unique way of life yet represent a high degree of heterogeneity in many features including cultural characteristics and social status [95]; and (c) routinely interact with the dominant culture [96].

Data were collected between December 2016 and April 2017 using a two-stage cluster survey conducted in a major metropolitan region in northern Israel. The cultural heterogeneity of this region provides ample opportunity for Israeli-Arab individuals to interact with the population of the dominant culture. Firstly, the Arab population was divided into 125 geographic clusters (i.e., towns, villages), among which 30 clusters were randomly selected. In the second stage, households were randomly sampled based on an address list, and one adult member was interviewed face-to-face. A simple random sampling method is 
considered a fair way to select truly representative samples from larger populations since every population member has an equal chance of being selected [97].

Trained research assistants randomly approached 220 adults and requested them to participate in the survey in exchange for payment of NIS20 ( USD 5.50). The questionnaire consisted of measures of the research variables including demographics, and took about 30 minutes to complete. All participants were required to have some experience with Facebook, the leading open social media application in Israel, where people of different cultures easily communicate with each other. Given the cross-cultural nature of the research, we followed the recommended procedure for such studies [98,99].

Specifically, the questions were first written in English, translated into Arabic, and then into English again by a professional translator and by one of the authors whose native language is Arabic. The questionnaire and its scales were pretested on 15 respondents, refined, and translated again into English. To ensure face validity, respondents were asked about the clarity of the statements, and, in particular, about the extent to which items represented the constructs they aimed to reflect. A bilingual research assistant was closely involved at all stages, identifying and resolving the cases where the Arabic concepts did not convey the original intentions.

To avoid data collection biases (e.g., social desirability, interviewer effects) and to ensure high data quality, several steps were taken. First, there was standardization of the interview situation: Questions were formulated in such a way that the interviewers could immediately obtain answers from respondents that fit the response format [100]. Accordingly, interviewers were not required to provide respondents with further explanations before answering the questions. Second, skilled and well-trained interviewers were recruited for the purpose of collecting the data [101]. This method is of great importance, in particular when it comes to avoiding interviewer effects, as highly skilled interviewers contribute to achieving a more standardized interviewing process [102,103]. Finally, to reduce the effects of social desirability, self-administered questionnaires were employed. Namely, the questionnaires were completed by the respondents themselves [104].

Participants (55\% female) were all experienced Facebook users with varying levels of usage intensity ( $18 \%$ low, $48 \%$ moderate, 34\% high). Ages ranged from 19 to 69 years of age $(\mathrm{M}=34 ; \mathrm{SD}=11.7)$. The majority of participants had post-secondary education $(66 \%)$, with average income or above (61\%).

\subsection{Measurement}

The questionnaire was based on nine validated scales adapted from past research (see Table 1). Two scales were applied in their exact original forms. Minority consumers intention to engage with eWOM communicated with other consumers from the dominant culture was measured on a bi-dimensional scale developed by Gvili and Levy [14]. This scale measures two behavioral aspects of engagement: ITR and ITS. The additional seven scales were adjusted to the context of the present study, which focuses on eWOM communications between minority and majority culture consumers. Attitudes toward eWOM shared with DC were measured using a scale adapted from Gvili and Levy [105], by referring specifically to product recommendations. Subjective norms and PBC were measured based on Fu et al. [106], by referring specifically to receiving/sending product recommendations on social media. The scale used to measure acculturation was based on Cuellar et al. [107], by adjusting items to the correct lingual and geographic context. Social interactions with members of the host society were measured using a scale adapted from Chiu, Hsu, and Wang [108], by referring to the DC community. The perceived language proficiency scale was taken from Sheldon [109], by adjusting items to the correct lingual context. Finally, cultural distance was measured using a scale based on Demes and Geeraert [110], by adjusting items to the context of the MC. 
Table 1. Factor Loadings and Variables' Reliability and Validity Measures.

\begin{tabular}{|c|c|c|c|c|}
\hline Variables and Items & $\begin{array}{l}\text { Standardized } \\
\text { Coefficients }\end{array}$ & $\begin{array}{c}\text { EFA } \\
\text { Loadings }\end{array}$ & $\begin{array}{l}\text { Composite } \\
\text { Reliability }\end{array}$ & $\begin{array}{l}\text { Cronbach's } \\
\text { Alpha }\end{array}$ \\
\hline \multicolumn{5}{|l|}{$\begin{array}{l}\text { Directions: Participants were instructed that the statements } \\
\text { below are related to their communications with individuals } \\
\text { from the culture of the majority population. }\end{array}$} \\
\hline Intention to Receive (ITR) ${ }^{\text {a }}[14]$ & & & 0.94 & 0.90 \\
\hline $\begin{array}{l}\text { 1. I usually read recommendations on products and services } \\
\text { on social media. }\end{array}$ & $0.88^{*}$ & 0.76 & & \\
\hline $\begin{array}{l}\text { 2. Most of the time, I am pleased to read on social media } \\
\text { about the experiences other people have had with products } \\
\text { and services that interest me. }\end{array}$ & $0.95 *$ & 0.85 & & \\
\hline $\begin{array}{l}\text { 3. When I see them on social media, I am open to receiving } \\
\text { other peoples' opinions on interesting products or services. }\end{array}$ & $0.92 *$ & 0.71 & & \\
\hline Intention To Send (ITS) ${ }^{a}[14]$ & & & 0.94 & 0.90 \\
\hline $\begin{array}{l}\text { 1. I tend to share my consumption experiences with others } \\
\text { on social media after using a new product. }\end{array}$ & $0.89 *$ & 0.74 & & \\
\hline $\begin{array}{l}\text { 2. When I receive valuable information on social media } \\
\text { about products or services, I usually forward it to others. }\end{array}$ & 0.94 * & 0.87 & & \\
\hline $\begin{array}{l}\text { 3. When I receive information on social media about } \\
\text { products or services, I tend to express my opinion there. }\end{array}$ & $0.91 *$ & 0.88 & & \\
\hline Attitude ${ }^{a}[111]$ & & & 0.93 & 0.88 \\
\hline $\begin{array}{l}\text { 1. In general, recommendations about products and services } \\
\text { on social media are a good thing. }\end{array}$ & $0.90 *$ & 0.78 & & \\
\hline $\begin{array}{l}\text { 2. In general, I like receiving recommendations about } \\
\text { products and services on social media. }\end{array}$ & $0.92 *$ & 0.81 & & \\
\hline $\begin{array}{l}\text { 3. In general, recommendations about products and services } \\
\text { on social media are a positive thing. }\end{array}$ & 0.88 * & 0.66 & & \\
\hline Subjective Norms ${ }^{\text {a }}[106]$ & & & 0.94 & 0.90 \\
\hline $\begin{array}{l}\text { 1. People who influence my behavior think that I should use } \\
\text { social media to receive or share recommendations about } \\
\text { products and services. }\end{array}$ & $0.90 *$ & 0.84 & & \\
\hline 2. People who are important to me think that I should use & & & & \\
\hline $\begin{array}{l}\text { social media to receive or share recommendations about } \\
\text { products and services. }\end{array}$ & $0.91 *$ & 0.75 & & \\
\hline $\begin{array}{l}\text { 3. People whose opinions I appreciate think that I should use } \\
\text { social media to receive or share recommendations about } \\
\text { products and services. }\end{array}$ & $0.93 *$ & 0.72 & & \\
\hline Perceived Behavioral Control (PBC) ${ }^{a}[106]$ & & & 0.93 & 0.88 \\
\hline $\begin{array}{l}\text { 1. I have control over using social media to receive or share } \\
\text { recommendations about products and services. }\end{array}$ & $0.83 *$ & 0.77 & & \\
\hline $\begin{array}{l}\text { 2. I have the resources necessary to use social media to } \\
\text { receive or share opinions about products and services. }\end{array}$ & 0.94 * & 0.87 & & \\
\hline $\begin{array}{l}\text { 3. I have the knowledge necessary to use social media to } \\
\text { receive or share recommendations about products and } \\
\text { services. }\end{array}$ & $0.91 *$ & 0.74 & & \\
\hline Acculturation [107] & & & 0.91 & 0.87 \\
\hline 1. I am pleased when I listen to Israeli music. & $0.87 *$ & 0.81 & & \\
\hline 2. I feel satisfied when I use Hebrew. & $0.94 *$ & 0.83 & & \\
\hline $\begin{array}{l}\text { 3. I enjoy reading Israeli literature (e.g., books or } \\
\text { newspapers). }\end{array}$ & $0.90 *$ & 0.78 & & \\
\hline 4. I like to define myself as an Israeli. & $0.69 *$ & 0.77 & & \\
\hline Social Interaction $[108]$ & & & 0.93 & 0.88 \\
\hline $\begin{array}{l}\text { 1. I have frequent communication with some members } \\
\text { outside my community. }\end{array}$ & $0.87 *$ & 0.84 & & \\
\hline $\begin{array}{l}\text { 2. I spend a lot of time interacting with some members } \\
\text { outside my community. }\end{array}$ & 0.93 * & 0.86 & & \\
\hline $\begin{array}{l}\text { 3. I maintain close social relationships with some members } \\
\text { outside my community. }\end{array}$ & 0.90 * & 0.80 & & \\
\hline
\end{tabular}


Table 1. Cont

\begin{tabular}{|c|c|c|c|c|}
\hline Variables and Items & $\begin{array}{l}\text { Standardized } \\
\text { Coefficients }\end{array}$ & $\begin{array}{c}\text { EFA } \\
\text { Loadings }\end{array}$ & $\begin{array}{l}\text { Composite } \\
\text { Reliability }\end{array}$ & $\begin{array}{l}\text { Cronbach's } \\
\text { Alpha }\end{array}$ \\
\hline Language Proficiency [109] & & & 0.94 & 0.91 \\
\hline 1. I speak Hebrew with family or close friends. & $0.89 *$ & 0.85 & & \\
\hline 2. I read Hebrew newspapers/magazines/books. & 0.95 * & 0.88 & & \\
\hline 3. I write Hebrew well. & $0.93 *$ & 0.78 & & \\
\hline Cultural Distance [110] & & & 0.87 & 0.78 \\
\hline $\begin{array}{l}\text { 1. In terms of family lifestyle, my culture is different than the } \\
\text { culture of the majority population. }\end{array}$ & 0.87 * & 0.83 & & \\
\hline $\begin{array}{l}\text { 2. In terms of food consumption, my culture is different than } \\
\text { the culture of the majority population. }\end{array}$ & $0.82 *$ & 0.81 & & \\
\hline $\begin{array}{l}\text { 3. In terms of values and beliefs, my culture is different than } \\
\text { the culture of the majority population. }\end{array}$ & $0.81 *$ & 0.80 & & \\
\hline
\end{tabular}

Notes: ${ }^{*} p<0.01,{ }^{a}$ : items are related to minority participants' communications with individuals from the culture of the majority population.

Respondents were asked to rate their agreement with the statements above concerning their engagement with eWOM communication with other consumers that belong to the dominant culture, on a seven-point Likert scale from one (strongly disagree) to seven (strongly agree). The statements were all related to participant product- and brand-related communication activities (such as reading/sharing others' product recommendations, product experiences, and product opinions) involving consumers from the Israeli majority population. Research assistants explicitly explained to the participants that the items on the questionnaire refer to such product- and brand-related communication activities with other consumers of the dominant culture.

\section{Results}

\subsection{Validity and Reliability}

All variable items were subjected to an exploratory factor analysis (EFA). The extraction method used was principal component analysis with varimax rotation. EFA yielded nine factors that explain $82.19 \%$ of the model's cumulative variance. All items were satisfactorily loaded on the scales they were designed to measure $(>0.60)$. Cronbach's alphas for model components were satisfactory $(>0.70)$.

\subsection{Common Method Bias}

The use of self-report data entails a potential problem of common method bias (CMB) occurrence. This problem was addressed both by the design of the study's procedure and its statistical controls, as proposed by Podsakoff et al. [112]. At the design level, respondents were guaranteed anonymity and confidentiality. They were also assured that there were no right or wrong answers and were requested to answer the questions honestly. These instructions should reduce participants' social desirability, which is a key source of common method bias, and their evaluation apprehension. In addition, all participants were experienced with Facebook, which further reduced the likelihood of CMB occurrence [113]. Statistical tests were conducted to gauge the extent of CMB in the data [112]. Harman's single-factor test [114] shows that the single factor accounted for a small share of the total variance $(37.0 \%)$. This suggests that common method effects were not likely to bias the results observed in this investigation.

\subsection{Empirical Findings}

Structural equation modelling (SEM) employing SmartPLS 3.0 was used for the analysis. Bootstrapping samples of 5000 were retained. Several alternative models were analyzed and compared, following an acceptable procedure proposed in past research [115]. The model with the best fit was retained as the final model. 
Results indicate an acceptable fit of the model. The measures of discrepancy are below their corresponding $\mathrm{HI}_{95}$ value. That is, the discrepancy between the empirical correlation matrix and the model implied that the correlation matrix is insignificant [116]. As follows, the standardized root mean square residual (SRMR) is $0.061\left(\mathrm{HI}_{95}=0.063\right)$, which is lower than the acceptable value of 0.08 . The geodesic discrepancy $\left(d_{G}\right)$ is $0.880\left(\mathrm{HI}_{95}=22.746\right)$, and the unweighted least squares discrepancy $\left(d_{U L S}\right)$ is $1.515\left(\mathrm{HI}_{95}=1.591\right)$ [117]. Moreover, the value of normed fit index (NFI) is 0.800 , which is within a satisfactory level [118].

Convergent validity meets the recommended threshold values for both composite reliability $(C R>0.70)$ [119] and average variance extracted (AVE $>0.50)$ [120]. The square root of AVE for each variable is greater than the correlations between the variables and all other variables in the model, signifying that these variables have discriminant validity. Discriminant validity is further verified by using the HeteroTrait-MonoTrait (HTMT) criterion [121], which is less than 0.90 [121,122], and all individual values fall within the confidence interval. Finally, variance inflation factor (VIF) values meet the recommended threshold (VIF < 5.0) [123]. Additionally, the average variance inflation factor (AVIF = 1.60) is lower than 5, as recommended [124], and therefore, indicates no collinearity. Overall, the proposed model exhibits adequate reliability, construct validity, and collinearity (see Table 2).

Table 2. VIF, AVE, Correlations and Heterotrait-Monotrait Ratio (HTMT).

\begin{tabular}{lccccccccccc}
\hline \multicolumn{1}{c}{ Construct } & VIF & AVE & $\mathbf{1}$ & $\mathbf{2}$ & $\mathbf{3}$ & $\mathbf{4}$ & $\mathbf{5}$ & $\mathbf{6}$ & $\mathbf{7}$ & $\mathbf{8}$ & $\mathbf{9}$ \\
\hline 1. ITR & 2.02 & 0.84 & $\mathbf{0 . 9 1}$ & 0.64 & 0.76 & 0.55 & 0.58 & 0.40 & 0.34 & 0.38 & 0.37 \\
2. ITS & 1.75 & 0.83 & $0.58^{* *}$ & $\mathbf{0 . 9 1}$ & 0.58 & 0.57 & 0.46 & 0.40 & 0.33 & 0.27 & 0.21 \\
3. Attitude & 2.25 & 0.81 & $0.69^{* *}$ & $0.51^{* *}$ & $\mathbf{0 . 9 0}$ & 0.65 & 0.63 & 0.38 & 0.39 & 0.38 & 0.33 \\
4. Subjective Norms & 1.81 & 0.83 & $0.47^{* *}$ & $0.51^{* *}$ & $0.53^{* *}$ & $\mathbf{0 . 9 1}$ & 0.64 & 0.35 & 0.37 & 0.23 & 0.34 \\
5. PBC & 1.73 & 0.82 & $0.49^{* *}$ & $0.39^{* *}$ & $0.52^{* *}$ & $0.55^{* *}$ & $\mathbf{0 . 9 0}$ & 0.29 & 0.44 & 0.41 & 0.29 \\
6. Acculturation & 1.21 & 0.73 & $0.27^{* *}$ & $0.30^{* *}$ & $0.18^{* *}$ & $0.31^{* *}$ & $0.23^{* *}$ & $\mathbf{0 . 8 5}$ & 0.41 & 0.57 & 0.24 \\
7. Social Interaction & 1.17 & 0.81 & $0.33^{* *}$ & $0.30^{* *}$ & $0.34^{* *}$ & $0.31^{* *}$ & $0.35^{* *}$ & $0.31^{* *}$ & $\mathbf{0 . 9 0}$ & 0.55 & 0.07 \\
8. Language Proficiency & 1.16 & 0.85 & $0.32^{* *}$ & $0.22^{* *}$ & $0.29^{* *}$ & $0.20^{* *}$ & $0.34^{* *}$ & $0.50^{* *}$ & $0.49^{* *}$ & $\mathbf{0 . 9 2}$ & 0.25 \\
9. Cultural Distance & 1.13 & 0.69 & $0.32^{* *}$ & $0.19^{* *}$ & $0.29^{* *}$ & $0.25^{* *}$ & $0.20^{* *}$ & $0.16^{*}$ & 0.05 & $0.18^{* *}$ & $\mathbf{0 . 8 3}$ \\
\hline
\end{tabular}

Notes: ${ }^{*} p<0.05,{ }^{* *} p<0.01$; VIF $=$ variance inflation factor; AVE = average variance extracted; correlations are displayed below the diagonal. HTMT values are displayed above the diagonal; square roots of average variances extracted (AVEs) shown on diagonal.

\subsection{Hypothesis Testing}

Model testing results show path coefficients and total variance explained for each of the dependent variable: ITR and ITS (see Table 3, Figure 2). The model exhibits high explanatory power of $50 \%$ for ITR and $41 \%$ for ITS. Stone-Geisser's Q2 values confirm its predictive relevancy [117], as all Q2 values are greater than zero.

$\mathrm{H} 1 \mathrm{a}$ and $\mathrm{H} 1 \mathrm{~b}$ propose that minority consumers' attitudes toward eWOM are positively related to minority consumers' intentions to receive and send eWOM. The results support H1a regarding attitude relationship with ITR $(\beta=0.50, p<0.01)$, but not $\mathrm{H} 1 \mathrm{~b}$ regarding the relationship with ITS $(\beta=0.10, p>0.05)$. The results also show that ITR is positively associated with ITS as part of the overall consumer engagement $(\beta=0.37, p<0.01)$. A mediation analysis reveals that ITR fully mediates the effect of consumer attitude on ITS ( $\beta=0.32,95 \%$ CI: $0.23-0.42, t=6.53$; Sobel $Z=3.93, p<0.01$ ).

$\mathrm{H} 2 \mathrm{a}$ and $\mathrm{H} 2 \mathrm{~b}$ suggest that minority consumers' subjective norms to engage with eWOM are positively related to ITR and ITS. The results show statistical support for $\mathrm{H} 2 \mathrm{~b}$ (ITS: $\beta=0.25, p<0.01$ ), but not for H2a (ITR: $\beta=0.07, p>0.05$ ). That is, subjective norms are positively related to ITS as hypothesized, but not to ITR. 
Table 3. Results of Hypotheses Testing.

\begin{tabular}{|c|c|c|c|c|}
\hline Hypothesis & Path Relationship & $\begin{array}{c}\text { Path } \\
\text { Coefficient }\end{array}$ & S.E. & $\mathbf{t}$ \\
\hline H1a & Attitude $\rightarrow$ Intention to Receive & 0.50 & 0.08 & $6.52 * *$ \\
\hline $\mathrm{H} 1 \mathrm{~b}$ & Attitude $\rightarrow$ Intention to Send & 0.10 & 0.08 & 1.25 \\
\hline $\mathrm{H} 2 \mathrm{a}$ & Subjective Norms $\rightarrow$ Intention to Receive & 0.07 & 0.08 & 0.88 \\
\hline $\mathrm{H} 2 \mathrm{~b}$ & Subjective Norms $\rightarrow$ Intention to Send & 0.25 & 0.07 & $3.52 * *$ \\
\hline $\mathrm{H} 3 \mathrm{a}$ & Behavioral Control $\rightarrow$ Intention to Receive & 0.17 & 0.08 & $1.99 *$ \\
\hline $\mathrm{H} 3 \mathrm{~b}$ & Behavioral Control $\rightarrow$ Intention to Send & 0.01 & 0.08 & 0.12 \\
\hline $\mathrm{H} 4$ & Acculturation $\rightarrow$ Attitude & 0.20 & 0.08 & $2.72 * *$ \\
\hline $\mathrm{H} 5 \mathrm{a}$ & Acculturation $\rightarrow$ Intention to Receive & 0.13 & 0.05 & $2.53 *$ \\
\hline $\mathrm{H} 5 \mathrm{~b}$ & Acculturation $\rightarrow$ Intention to Send & 0.14 & 0.07 & $1.90^{+}$ \\
\hline H6 & $\begin{array}{c}\text { Language Proficiency } \rightarrow \text { Behavioral } \\
\text { Control }\end{array}$ & 0.23 & 0.07 & $3.46^{* *}$ \\
\hline H7 & Social Interaction $\rightarrow$ Subjective Norms & 0.16 & 0.06 & $2.91 * *$ \\
\hline $\mathrm{H} 8 \mathrm{a}$ & $\begin{array}{c}\text { Cultural Distance } \times \text { Acculturation } \rightarrow \\
\text { Attitude }\end{array}$ & -0.17 & 0.07 & -2.54 * \\
\hline $\mathrm{H} 8 \mathrm{~b}$ & $\begin{array}{c}\text { Cultural Distance } \times \text { Language Proficiency } \\
\rightarrow \text { Behavioral Control }\end{array}$ & -0.23 & 0.04 & $-5.27^{* *}$ \\
\hline
\end{tabular}

Note: ${ }^{\dagger} p<0.10 ;{ }^{*} p<0.05 ;{ }^{* *} p<0.01$.

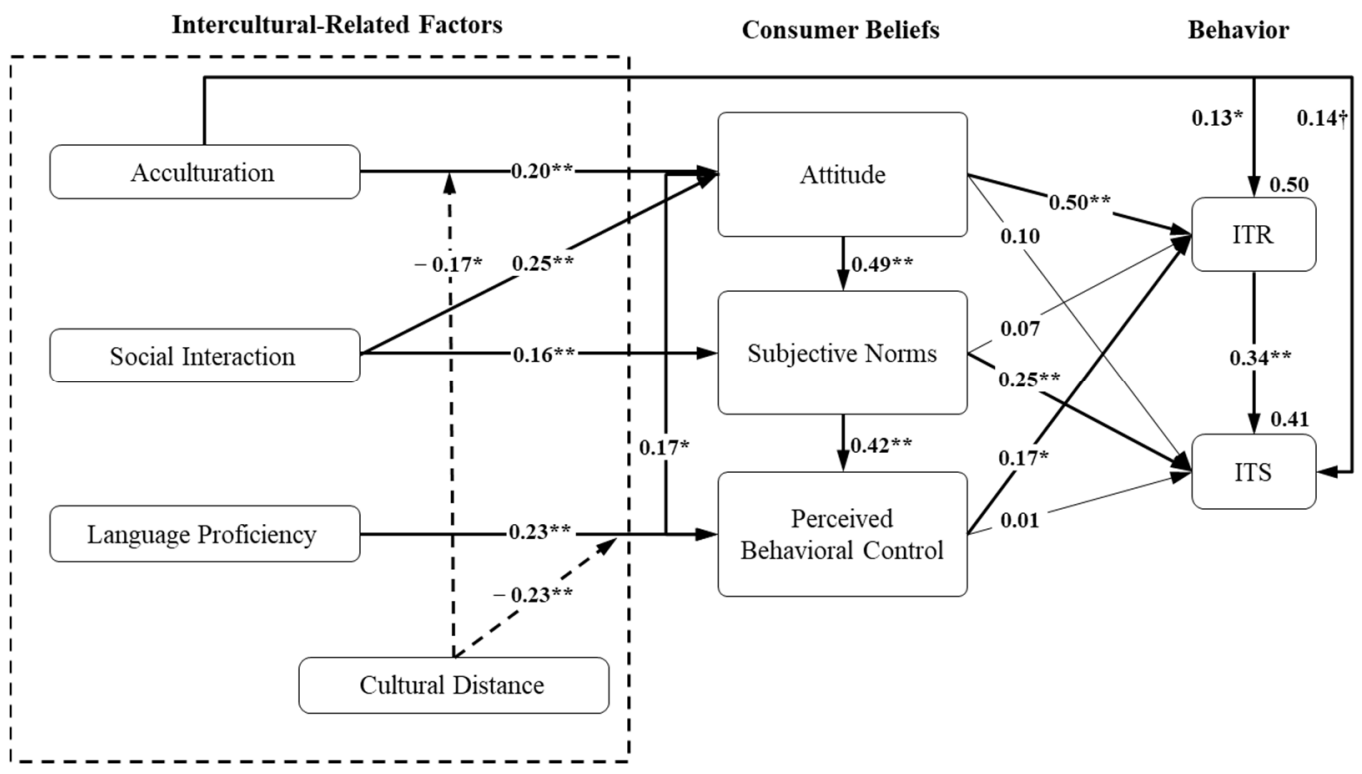

Figure 2. Conceptual Model Testing. Note: Path parameters are standardized parameter estimates; dashed arrows indicate moderation; $R^{2}$ are depicted in the right-hand corner; $+p<0.10 ;{ }^{*} p<0.05$; ** $p<0.01$.

$\mathrm{H} 3 \mathrm{a}$ and $\mathrm{H} 3 \mathrm{~b}$ suggest that minority consumers' perceived behavioral control to engage with eWOM communicated with DC members is positively related to ITR and ITS. The results reveal that $\mathrm{PBC}$ is positively related to $\operatorname{ITR}(\beta=0.17, p<0.05)$ but not to ITS $(\beta=0.01$, $p>0.05)$. Yet, PBC has a marginal indirect relationship with ITS, which is mediated by ITR ( $\beta=0.06,95 \%$ CI: $0.01-0.14$, Sobel $Z=1.79, p=0.07)$. Therefore, H3a is supported while $\mathrm{H} 3 \mathrm{~b}$ is not supported.

H4 predicts a positive relationship between minority consumer acculturation with DC and attitude. The results revealed positive relationships between acculturation and attitude $(\beta=0.20, p<0.01)$. Hence, $\mathrm{H} 4$ is supported. Results also show an indirect effect of acculturation on engagement with eWOM on both dimensions; ITR $(\beta=0.12, \mathrm{t}=2.61$; $p<0.05$; 95\% CI: 0.03-0.22, Sobel $\mathrm{Z}=2.51, p<0.05)$ and ITS $(\beta=0.13, \mathrm{t}=3.01 ; p<0.05$; $95 \%$ CI: $0.05-0.22$, Sobel $Z=2.18 ; p<0.05)$. Attitude is also positively related to subjective 
norms $(\beta=0.49, p>0.01)$. Consequently, acculturation has an indirect effect on subjective norms, which is mediated by attitude $(\beta=0.10,95 \%$ CI: $0.03-0.18$, Sobel $Z=2.61, p<0.01)$.

$\mathrm{H} 5 \mathrm{a}$ and $\mathrm{H} 5 \mathrm{~b}$ suggest that minority consumer acculturation with the DC is positively and directly related to ITR and ITS. The results reveal that acculturation is positively related to ITR ( $\beta=0.13, p<0.05)$ but only marginally to ITS $(\beta=0.14, p=0.06)$. Therefore, H5a is supported while $\mathrm{H} 5 \mathrm{~b}$ is marginally supported.

H6 addresses the effect of perceived language proficiency of minority consumers on their perceived behavioral control to engage with eWOM communication with DC members. The results support the hypothesized relationship $(\beta=0.23, p<0.01)$ which supports H6.

H7 suggests a positive relationship between social interaction of minority consumers with DC members and the subjective norms of the former to engage with eWOM. The results revealed a positive relationship between social interaction and subjective norms $(\beta=0.16, p<0.01)$. Thus, H7 is supported. In addition, we found a direct effect of social interaction on attitude $(\beta=0.25, p<0.01)$. These results further reveal that attitude mediates the effect of social interaction on ITR $(\beta=0.17, \mathrm{t}=3.64 ; p<0.01 ; 95 \% \mathrm{CI}$ : $0.08-0.27$, Sobel $\mathrm{Z}=3.08, p<0.01)$, and on ITS $(\beta=0.15, \mathrm{t}=3.72 ; p<0.05 ; 95 \% \mathrm{CI}: 0.07-0.24$; Sobel $\mathrm{Z}=2.51$, $p<0.05)$.

Cultural distance was hypothesized $(\mathrm{H} 8 \mathrm{a}, \mathrm{H} 8 \mathrm{~b})$ as a factor moderating the effects of intercultural factors (e.g., acculturation, perceived language proficiency,) on MC individuals' beliefs regarding their engagement with eWOM (attitudes and PBC). The results show that cultural distance negatively moderates the positive relationship of acculturation and attitudes $(\beta=-0.17, p<0.01)$, supporting H8a.

Finally, H8b suggests that cultural distance negatively moderates the effect of perceived language proficiency on PBC. The results offer statistical support for this proposed relationship $(\beta=-0.23, p<0.01)$. Therefore, $\mathrm{H} 8 \mathrm{~b}$ is supported.

Taking the above together, the study results indicate that the three behavioral antecedents are mediators of consumer intention to engage with eWOM communication that originated from the dominant culture. This is consistent with the theory of planned behavior. However, intercultural factors (e.g., acculturation) may create an alternative direct route to engagement with eWOM.

Furthermore, the current study approaches intercultural eWOM engagement in a unique way that distinguishes between minority consumer intentions to receive and share eWOM. Our findings reveal that the behavioral processes that result in each class of engagement are distinct and contingent on different consumer beliefs. ITR is mainly associated with consumer attitudes and their sense of behavioral control, while ITS depends on subjective norms. These two dimensions of consumer engagement differ by the level of activation and effort they involve. While receiving eWOM is a relatively passive action, sharing eWOM requires a higher level of consumer activation. The act of sharing often requires consumers to forward their social contacts a message they have already received, or take the initiative and create a new message. This explains why the effects of two key consumers beliefs (i.e., attitude, PBC) on ITS are mediated by ITR. Unlike receiving eWOM, the outcomes of sharing eWOM with one's social contacts is visible to others, and may involve face concerns [125] regarding the influence on one's image in the context of social interaction [126]. Therefore, this behavior potentially affects the way they are perceived by their social circles. This may explain why subjective norms are the only direct predictor of ITS.

Additionally, a minority consumer's intention to send eWOM is mainly a matter of community norms as she interprets them but not of her perceived personal abilities or skills. This suggests that minority consumers may hesitate to send eWOM on SNS to outsiders even though they have the personal resources to do so. Social exchange theory (SET) [127] may explain this hesitation. According to SET, a required condition for social exchange is that the exchanging parties perceive each other as capable of delivering and benefiting from the exchanged value. Therefore, minority consumers may be reluctant 
to communicate with SNS users outside their community if they are perceived as being incapable of interpreting outgroup messages.

The findings suggest that minority consumer acculturation affects engagement with eWOM along two paths. In one path, acculturation is directly tied to eWOM engagement. This indicates that as minority individuals become more acculturated to the host society (i.e., DC), they may be drawn culturally closer [72] and consequently have more opportunities to engage with the host society. Hence, engagement with eWOM on social media may be an expression of minority acculturation [51]. This view is also supported by SIT as acculturation may cultivate the sense of belonging of minority individuals to the dominant culture, which motivates engagement with DC group individuals [128].

In the second path, minority consumer acculturation influences their attitudes and subjective norms to engage with eWOM. This implies that as ethnic minorities become acculturated with the host society, cultural elements are mutually conveyed and reduce communication-inhibiting factors. In turn, MC consumers become more open to dominant culture consumer norms, and may adopt the host society's values, which may also increase MC consumer inclination to engage with DC consumer eWOM communications [40]. These findings are consistent with previous studies showing that acculturation reduces the gap between cultures in terms of consumer attitudes and subjective norms [72]. Through acculturation, $\mathrm{MC}$ consumers who recognize the benefits of DC-originated eWOM are more open to accepting the behavioral norms of DC consumers [66]. Consequently, the majority's values may better resonate with MC consumers, who consequently develop a more positive attitude toward eWOM communicated by DC consumers $[47,73,105]$.

Social interactions with DC members establish new affiliations and identities for MC members [129]. Accordingly, MC consumers who socially interact with DC members are more likely to perceive their social circle's norms as supportive of eWOM engagement with the DC community [130]. Perceived social approval further translates into increased intention to send eWOM to DC consumers because sending messages may reveal one's identity, which requires social approval. This finding corresponds with past research suggesting that intercultural social interactions enhance minorities' sense of belongingness to the dominant culture and their use of the dominant culture as a reference group [89]. Accordingly, MC members who interact extensively with the DC are more likely to perceive engagement with eWOM that originated with DC consumers as acceptable behavior that is sanctioned by their own social circle.

In line with previous research [86], our findings demonstrate that DC language proficiency enhances the sense of control of MC individuals over the DC social media environment [80], and improves interaction with outgroup members [81].

Cultural distance moderates the effect of intercultural factors on consumer beliefs regarding engagement with eWOM. Acculturation of MC members has a significantly stronger positive effect on attitude when cultural distance is small (see Figure 3a). This finding is in accordance with previous studies that report that acculturation is motivated by cultural distance [17]. High cultural distant MC members find it harder to adopt the values and norms of the dominant cultural group [94]. Thus, they are less likely to appreciate the benefits resulting from engagement with eWOM communicated with DC members. Acculturation can mitigate these difficulties [66] and increase individual attitudes in support of engagement with eWOM, primarily when cultural distance is smaller. 


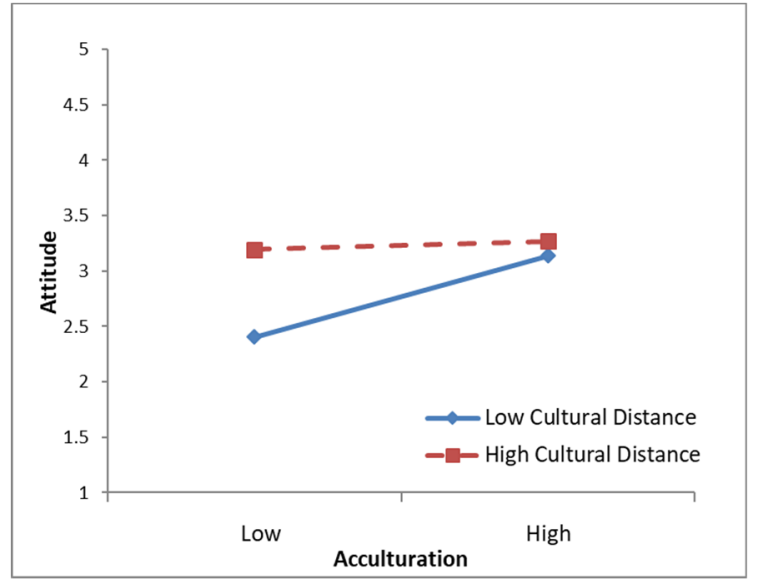

(a)

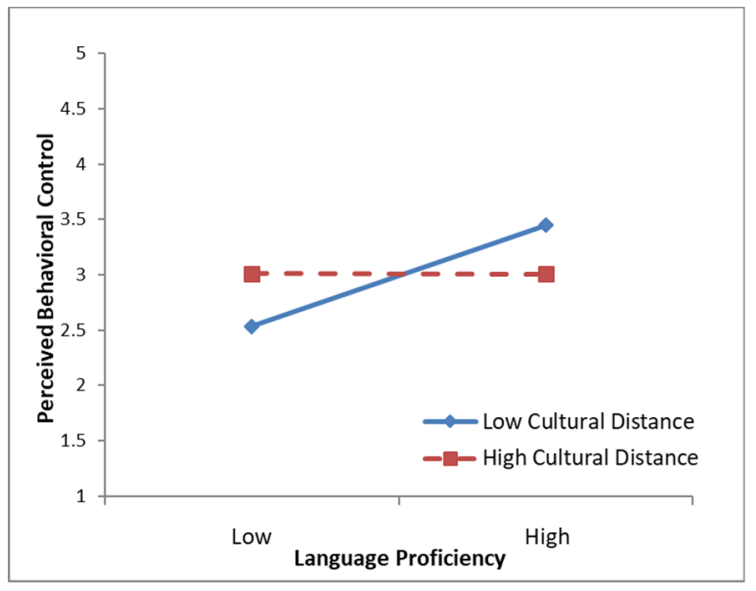

(b)

Figure 3. Moderation effects of cultural distance: (a) Moderates the relationship between acculturation of MC members and attitude; (b) moderates the relationship between language proficiency and PBC.

Cultural distance also negatively moderates the relationship between language proficiency and PBC (see Figure 3b). Minority proficiency of the host language can bridge the cultural distance from the dominant culture [131]. This in turn affects MC consumers' perceived ability to participate in or control interactions with DC consumers $[82,84]$. The current study demonstrates that MC consumers who are proficient in the dominant language perceive themselves to be able to engage more easily with eWOM communications that originated with DC consumers. When cultural distance is large, enhanced language proficiency will not affect minorities' PBC.

\section{Discussion}

Drawing upon the theory of planned behavior, the purpose of the current research was to model the effect of intercultural factors on minority consumers' engagement with eWOM communicated with members of the dominant culture. Overall, the findings support the notion that intercultural factors predict this effect, demonstrating that the association is mediated by minority consumers' attitudes, social norms, and PBC of eWOM engagement.

\subsection{Theoretical Contributions}

The present study offers several theoretical contributions. First, the study contributes to the literature on ethnic consumer behavior by providing a new theoretical framework for understanding the effects of intercultural factors on minority consumers' behavior on social media. This study integrates intercultural factors with the theory of planned behavior [132] to explain minority consumers' engagement with eWOM communicated with members of the dominant culture.

Past research findings suggest that national culture predicts consumer engagement with both traditional WOM [133] and eWOM $[134,135]$. The present study contributes to this literature by demonstrating that cultural factors are important determinants of eWOM engagement even within the same national-social context. Further, the underlying mechanism of these effects is proposed to be consumer beliefs based on TPB.

In addition, one stream of previous research found that culture has moderating effects on consumer response to eWOM $[33,136,137]$, while another showed that culture acts as an antecedent of this behavior $[32,58]$. The current research findings contribute to bridging this gap, by demonstrating that some intercultural factors can act as moderators (e.g., cultural distance), while others act as antecedents (e.g., acculturation, social interaction).

Intercultural factors are numerous and extremely diverse. The present research theorizes that the nature of their effects on minority consumer behavior also varies significantly. By integrating four different intercultural factors into one conceptual model, we demon- 
strate their interplay. This entails that intercultural factor are highly complex in their effects as they have both direct effects on consumer behavior and interaction effects with other intercultural factors. Accordingly, the present study supports and extends past research.

Second, the present study contributes to the literature supporting the post-assimilationist view in consumer acculturation research $[21,22,71]$ by providing an explanation for the tendency of minority consumers to remain distinct, despite acculturation [66]. According to this theoretical view, ethnic minority consumers employ various ethnic consumption practices (e.g., consuming ethnic foods, wearing ethnic attire) as instruments to reinforce their identity in mixed cultural environments. The present study adds to this theory by asserting that the post-assimilationist view is mainly applicable to polarized cultural settings, that is, in high cultural distance contexts. When cultural distance is sufficiently large, acculturation does not encourage communications regarding consumer choices or opinions (i.e., eWOM) between the minority and dominant culture groups, because such communication is not instrumental for supporting minorities' ethnic identity. For example, acculturated Canadian immigrants in the US may be more inclined to engage in reading and sharing American consumers' products online reviews on Facebook than acculturated Syrian immigrants.

Furthermore, the findings of the present research provide an additional explanation for the argument that minority consumer engagement in eWOM on social media is multidimensional [15]. Because engagement behavior is preceded by consumer beliefs (e.g., attitude), the multi-layered nature of these beliefs [138] allows minority consumers to hold a positive attitude toward sharing eWOM on a particular topic (e.g., reviewing baby diapers) but a negative attitude regarding others (e.g., recommending video games). This is also consistent with the post-assimilationist view, which also accepts that acculturation can result in minority adaptation, in some respects, to the dominant culture while remaining distinct in others.

Third, the study contributes to the literature on consumer engagement. Engagement theory asserts that engagement is context-specific in that it varies across brands and products $[139,140]$ The framework presented in this paper supports this flexible theoretical approach and extends it by demonstrating that engagement is contingent on the socialintercultural context in which eWOM communications occur. The extended perspective of engagement is rooted in the consumer engagement behavior model [34], which integrates customer-based and context-based factors (e.g., intercultural-related factors) with firm-based factors (brand-related factors).

\subsection{Managerial and Practical Implications}

As consumer social activity and media consumption shift from traditional channels to social media, and with the expansion of digital trade [141-143], the rising power of consumers in digital media [144] creates new challenges for marketers: consumers can follow brands, interact with messages, and share and amplify their impact, yet also have the ability to filter out marketing messages at will. This aspect of consumer behavior may significantly influence the success of particular marketing campaigns or brands. Our findings can help marketers plan marketing communications that engage audiences meaningfully and generate positive electronic word of mouth when they target ethniccultural minorities.

The findings of the present study suggest that marketing practitioners should note the effects of intercultural factors on minority consumers' inclination to engage with brand-related eWOM shared by consumers from the dominant culture. First, engaging highly acculturated ethnic minority consumers with brand-related eWOM shared by the majority is an effective marketing strategy. For example, in promoting food brands to US-born Hispanics, marketers should use mainstream social media or apps, as this minority is highly acculturated in the general American culture $[145,146]$. Consequently, this group is inclined to accept and share product recommendations regardless of the ethnic affiliation of the sender. Nevertheless, this suggestion is less valid for low cultural distance 
contexts. Therefore, marketers should avoid initiating online brand-related conversations between culturally distant ethnic minorities and the majority group. Culturally distant minorities refrain from engaging with eWOM shared by the majority even if they are highly acculturated with the dominant culture. Targeting such minority consumers via closed ethnic Facebook groups, online ethnic communities, or niche websites may prove more effective in enhancing engagement with the marketing message.

In addition, the results can help improve the dissemination of opinions of consumers in diverse cultural groups via channels such as Facebook's News Feed and Twitter where social algorithms electronically customize the information presented to users. As these algorithms become increasingly complex and less transparent, their developers struggle to understand and harness their influence on consumer behavior [147]. Nevertheless, Facebook users' proactive choices influence their exposure to opinions of others with different viewpoints more strongly than algorithmic ranking [148]. Because people's friends generally are similar to them [149], consumer reliance on same-ethnicity Facebook users as a source of product information may result in ingroup bias with low outgroup eWOM engagement. Nonetheless, our findings suggest that incorporating factors such social interaction and language proficiency into social algorithms can diversify, and potentially improve, minority consumers' access to useful product information even if it originates with consumers of other ethnicities.

The findings also suggest that marketers can promote brand-related eWOM by encouraging online conversations between minority and majority cultural groups. Our findings suggest that more frequent social interactions reinforce minorities' perceived social norms that support engagement with eWOM shared with the dominant culture group. Accordingly, P\&G's 'The Talk' campaign discussed in the Introduction section demonstrates that incorporating topics that trigger conversations between minority- and majority-group consumers contributes to the marketing success of the brand.

Finally, marketers can proactively reduce minority consumers' perceived cultural distance from the dominant culture, hereby facilitating the positive effect of acculturation on engagement with eWOM. This may be particularly important due to the pivotal role of acculturation in the eWOM engagement formation process. By increasing minority representation and refraining from the use of stereotyping in their marketing communications, marketers can reduce perceived cultural distance, affirm minority ethnic identity, and identify minorities as an integral part of the fabric of the general community [150]. The resulting marketing benefit may be twofold enhancing the effectiveness of marketing campaigns, and attributing this desirable social change to the brand. These effects should be further considered by regulators and policy makers due to their potential to reduce social tension and enhance minorities' integration in society.

\subsection{Limitations and Future Research}

The present research has several notable limitations that should be addressed in future research. First, based on the theory of planned behavior and past empirical research $[47,57,151]$, the present research conceptualizes intercultural factors as antecedents of consumer engagement with eWOM. An alternative perspective supported by past research is that cultural factors can act as moderators rather than as antecedents [134,137,152]. Hence, it would be interesting to explore in future research the moderating role of the intercultural factors discussed in this paper.

Second, based on contact theory, the present research examines the effect of intercultural factors on MC consumer engagement with eWOM communicated with consumers of the dominant/majority culture (DC). As such, our findings are limited to predicting minority consumers' behavioral engagement. Because majority consumers have higher social status and access to more extensive resources [153], their behavioral engagement with eWOM on social media may vary from minority consumers' engagement [154]. Therefore, the findings reported in this paper may not be applicable to predicting behavioral engagement of majority consumers with minorities. Future research should examine the nature of domi- 
nant/majority consumer engagement with eWOM communicated with minority consumers. Nonetheless, although the host and minority cultures might influence each other, in reality, the acculturation process is asymmetrical, affecting the minority groups more strongly than the dominant population [66].

Third, the present study tested the effects of intercultural factors of a particular minority group (Israeli-Arab consumers). To increase the generalizability of the findings, future research should test the proposed theoretical framework with other minorities in additional and different cultural contexts. Finally, this research focuses on eWOM communication intentions rather than actual behavior. Collecting data based on eWOM behaviors such as number of likes, shares, and the extent of comments on social media would further improve the generalizability of the current study's results.

\section{Conclusions}

With the growing popularity of social media across various cultures and minorities it has become increasingly interesting to address the process by which minority eWOM behavior is influenced by intercultural factors. To accomplish this goal, in the present study, we developed a conceptual framework based on the theory of planned behavior [46] and intergroup contact theory [63]. The model depicts the role of intercultural factors (acculturation, social interaction, language proficiency, and cultural distance) as antecedents of minority culture (MC) consumer engagement with eWOM, which is communicated with the dominant cultural group.

A SEM-PLS analysis on data collected from the Israeli-Arab minority supported the theoretical model. The results show that intercultural factors can predict minority consumer engagement with eWOM communication that originated from the dominant culture. However, this outcome is mainly mediated via the three behavioral antecedents, i.e., minority consumer attitudes, social norms, and PBC of eWOM engagement. Additionally, the results indicate that cultural distance can moderate the effect of intercultural factors on consumer beliefs regarding engagement with eWOM.

This research contributes to theory and practice and its novelty rests on the unique social commerce dynamic that emerges from cultural gaps between minority and majority cultural groups and is relevant when different cultural groups interact with each other.

Author Contributions: Conceptualization, S.L., Y.G. and H.H.; methodology, S.L., Y.G. and H.H.; software, H.H.; validation, S.L., Y.G. and H.H.; formal analysis, S.L.; investigation, Y.G.; resources, S.L. and H.H.; data curation, Y.G.; writing-original draft preparation, S.L., Y.G. and H.H.; writingreview and editing, S.L., Y.G. and H.H.; visualization, Y.G.; supervision, H.H.; project administration Y.G.; funding acquisition, S.L. and H.H.. All authors have read and agreed to the published version of the manuscript.

Funding: This research received no external funding.

Institutional Review Board Statement: Approved by Ono Academic College (OAC) Ethics Committee. Informed Consent Statement: Informed consent was obtained from all subjects involved in the study.

Data Availability Statement: Data availability is upon request and consent of the authors.

Conflicts of Interest: The authors declare no conflict of interest.

$\begin{array}{ll}\text { Abbreviations } & \\ \text { Abbreviation } & \text { Details } \\ \text { AVE } & \text { Average Variance Extracted } \\ \text { AVIF } & \text { Average Variance Inflation Factor } \\ \text { CMB } & \text { Common Method Bias } \\ \text { CR } & \text { Composite Reliability }\end{array}$




$\begin{array}{ll}\text { DC } & \text { Dominant Culture } \\ \text { EFA } & \text { Exploratory Factor Analysis } \\ \text { WOM } & \text { Electronic Word of Mouth } \\ \text { HTMT } & \text { Hetero Trait-Mono Trait } \\ \text { ITR } & \text { Intention to Receive } \\ \text { ITS } & \text { Intention to Send } \\ \text { MC } & \text { Minority Culture } \\ \text { NFI } & \text { Normed Fit Index } \\ \text { PBC } & \text { Perceived Behavioral Control } \\ \text { PLS } & \text { Partial Least Squares } \\ \text { SEM } & \text { Structural Equation Modelling } \\ \text { SNS } & \text { Social Network Sites } \\ \text { SRMR } & \text { Standardized Root Mean Square Residual } \\ \text { Q2 } & \text { Stone-Geisser's Q2 } \\ \text { TPB } & \text { Theory of Planned Behavior } \\ \text { VIF } & \text { Variance Inflation Factor }\end{array}$

\section{References}

1. Martinez, O.; Wu, E.; Shultz, A.Z.; Capote, J.; Rios, J.L.; Sandfort, T.; Manusov, J.; Ovejero, H.; Carballo-Dieguez, A.; Baray, S.C. Still a hard-to-reach population? using social media to recruit latino gay couples for an HIV intervention adaptation study. J. Med. Internet Res. 2014, 16, e113. [CrossRef]

2. Migration and Migrant Population Statistics: c2018. Available online: https://ec.europa.eu/eurostat/statistics-explained/ index.php?title=Migration_and_migrant_population_statistics\#Migration_flows:_2_million_non-EU_immigrants (accessed on 10 October 2018).

3. P\&G Leads “The Talk" about Bias on Tonight's Episode of ABC's Black-Ish. Available online: https://news.pg.com/pressrelease/pg-corporate-announcements/pg-leads-talk-about-bias-tonights-episode-abcs-black-ish (accessed on 2 October 2018).

4. Which Side of History Is Your Brand On? P\&G's Marc Pritchard Says Now's the Time to Make It Clear. Available online: https: / / www.adweek.com/brand-marketing/which-side-of-history-is-your-brand-on-pgs-marc-pritchard-says-nowsthe-time-to-make-it-clear/ (accessed on 2 October 2018).

5. P\&G's 'The Talk' ad Stirs up Social Media, Earning Blowback and Praise. c2017. Available online: https://www.cincinnati.com/ story/money/2017/08/03/pg-procter-the-talk-ad-stirs-up-social-media-winning-praise-and-blowback/537163001/ (accessed on 2 October 2018).

6. Growing Pains: In Extending a Hand to New Audiences, Shea Moisture Rubs its Base the Wrong Way. Available online: https:/ / youngrestlesscreative.com/2017/05/02/growing-pains-in-extending-a-hand-to-new-audiences-shea-moisture-rubsits-base-the-wrong-way / (accessed on 2 October 2018).

7. Gray, R.; Vitak, J.; Easton, E.W.; Ellison, N.B. Examining social adjustment to college in the age of social media: Factors influencing successful transitions and persistence. Comput. Educ. 2013, 67, 193-207. [CrossRef]

8. Mesch, G.S. Minority status and the use of computer-mediated communication: A test of the social diversification hypothesis. Commun. Res. 2012, 39, 317-337. [CrossRef]

9. Fox, J.; Warber, K.M. Queer identity management and political Self-Expression on social networking sites: A Co-Cultural approach to the spiral of silence. J. Commun. 2015, 65, 79-100. [CrossRef]

10. Correa, T.; Jeong, S.H. Race and online content creation: Why minorities are actively participating in the web. Inf. Commun. Soc. 2011, 14, 638-659. [CrossRef]

11. De Vries, N.J.; Carlson, J. Examining the drivers and brand performance implications of customer engagement with brands in the social media environment. J. Brand Manag. 2014, 21, 495-515. [CrossRef]

12. Brodie, R.J.; Hollebeek, L.D.; Juric, B.; Ilic, A. Customer engagement: Conceptual domain, fundamental propositions, and implications for research. J. Serv. Res. 2011, 14, 252-271. [CrossRef]

13. Leckie, C.; Nyadzayo, M.W.; Johnson, L.W. Antecedents of consumer brand engagement and brand loyalty. J. Mark. Manag. 2016, 32, 558-578. [CrossRef]

14. Gvili, Y.; Levy, S. Consumer engagement with eWOM on social media: The role of social capital. Online Inf. Rev. 2018, 42, 482-505. [CrossRef]

15. Hollebeek, L.D.; Glynn, M.S.; Brodie, R.J. Consumer brand engagement in social media: Conceptualization, scale development and validation. J. Interact. Mark. 2014, 28, 149-165. [CrossRef]

16. Anastasiei, B.; Dospinescu, N. A model of the relationships between the big five personality traits and the motivations to deliver word-of-mouth online. Psihologija 2018, 51, 215-227. [CrossRef]

17. Berry, J.W. Acculturation as varieties of adaptation. In Acculturation Theory: Models and Some New Findings; Padilla, A.M., Ed.; Westview: Boulder, CO, USA, 1980.

18. Berry, J.W. Social and cultural change. In Handbook of Cross-Cultural Psychology; Brislin, R.W., Triandis, H.C., Eds.; Allyn \& Bacon: Boston, MA, USA, 1980. 
19. Deshpande, R.; Hoyer, W.D.; Donthu, N. The intensity of ethnic affiliation: A study of the sociology of hispanic consumption. J. Consum. Res. 1986, 13, 214-220. [CrossRef]

20. Hirschman, E.C. American jewish ethnicity: Its relationship to some selected aspects of consumer behavior. J. Mark. 1981, 45, 102-110. [CrossRef]

21. Peñaloza, L. Atravesando fronteras/border crossings: A critical ethnographic exploration of the consumer acculturation of mexican immigrants. J. Consum. Res. 1994, 21, 32-54. [CrossRef]

22. Askegaard, S.; Arnould, E.J.; Kjeldgaard, D. Postassimilationist ethnic consumer research: Qualifications and extensions. J. Consum. Res. 2005, 32, 160-170. [CrossRef]

23. Kizgin, H.; Jamal, A.; Rana, N.; Dwivedi, Y.; Weerakkody, V. The impact of social networking sites on socialization and political engagement: Role of acculturation. Technol. Forecast. Soc. Chang. 2019, 145, 503-512. [CrossRef]

24. Kizgin, H.; Jamal, A.; Dey, B.L.; Rana, N.P. The impact of social media on consumers' acculturation and purchase intentions. Inf. Syst. Front. 2018, 20, 503-514. [CrossRef]

25. Demangeot, C.; Broderick, A.J.; Craig, C.S. Multicultural marketplaces: New territory for international marketing and consumer research. Int. Mark. Rev. 2015, 32, 118-140. [CrossRef]

26. Lingreen, A.; Dobele, A.; Vanhamme, J.; Luís Abrantes, J.; Seabra, C.; Raquel Lages, C.; Jayawardhena, C. Drivers of in-group and out-of-group electronic word-of-mouth (eWOM). Eur. J. Mark. 2013, 47, 1067-1088.

27. Donthu, N.; Kumar, S.; Pandey, N.; Pandey, N.; Mishra, A. Mapping the electronic word-of-mouth (eWOM) research: A systematic review and bibliometric analysis. J. Bus. Res. 2021, 135, 758-773. [CrossRef]

28. Schamari, J.; Schaefers, T. Leaving the home turf: How brands can use webcare on consumer-generated platforms to increase positive consumer engagement. J. Interact. Mark. 2015, 30, 20-33. [CrossRef]

29. Anastasiei, B.; Dospinescu, N.; Dospinescu, O. Understanding the adoption of incentivized word-of-mouth in the online environment. J. Theor. Appl. Electron. Commer. Res. 2021, 16, 992-1007. [CrossRef]

30. Chen, A.; Lu, Y.; Wang, B.; Zhao, L.; Li, M. What drives content creation behavior on SNSs? A commitment perspective. J. Bus. Res. 2013, 66, 2529-2535. [CrossRef]

31. Hennig-Thurau, T.; Gwinner, K.P.; Walsh, G.; Gremler, D.D. Electronic word-of-mouth via consumer-opinion platforms: What motivates consumers to articulate themselves on the internet? J. Interact. Mark. 2004, 18, 38-52. [CrossRef]

32. Lee, C.H. Predictors of electronic word-of-mouth behavior on social networking sites in the united states and korea: Cultural and social relationship variables. Comput. Hum. Behav. 2019, 94, 9-18. [CrossRef]

33. Levy, S.; Gvili, Y. Online shopper engagement in price negotiation: The roles of culture, involvement and eWOM. Int. J. Advert. 2020, 39, 232-256. [CrossRef]

34. Van Doorn, J.; Lemon, K.N.; Mittal, V.; Nass, S.; Pick, D.; Pirner, P.; Verhoef, P.C. Customer engagement behavior: Theoretical foundations and research directions. J. Serv. Res. 2010, 13, 253-266. [CrossRef]

35. Harmeling, C.M.; Moffett, J.W.; Arnold, M.J.; Carlson, B.D. Toward a theory of customer engagement marketing. J. Acad. Mark. Sci. 2017, 45, 312-335. [CrossRef]

36. Ángeles Oviedo-García, M.; Muñoz-Expósito, M.; Castellanos-Verdugo, M.; Sancho-Mejías, M. Metric proposal for customer engagement in facebook. J. Res. Interact. Mark. 2014, 8, 327-344. [CrossRef]

37. Camarero, C.; San José, R. Social and attitudinal determinants of viral marketing dynamics. Comput. Hum. Behav. 2011, 27, 2292-2300. [CrossRef]

38. Busalim, A.H.; Hussin, A.R.C.; Iahad, N.A. Factors influencing customer engagement in social commerce websites: A systematic literature review. J. Theor. Appl. Electron. Commer. Res. 2019, 14, 1-14. [CrossRef]

39. Kumar, V.; Pansari, A. Competitive advantage through engagement. J. Mark. Res. 2016, 53, 497-514. [CrossRef]

40. Chu, S.; Kim, Y. Determinants of consumer engagement in electronic word-of-mouth (eWOM) in social networking sites. Int. J. Advert. 2011, 30, 47-75. [CrossRef]

41. Calder, B.J.; Malthouse, E.C.; Schaedel, U. An experimental study of the relationship between online engagement and advertising effectiveness. J. Interact. Mark. 2009, 23, 321-331. [CrossRef]

42. Shan, Y.; King, K.W. The effects of interpersonal tie strength and subjective norms on consumers' brand-related eWOM referral intentions. J. Interact. Advert. 2015, 15, 16-27. [CrossRef]

43. Han, T.; Stoel, L. Explaining socially responsible consumer behavior: A meta-analytic review of theory of planned behavior. J. Int. Consum. Mark. 2017, 29, 91-103. [CrossRef]

44. Rise, J.; Sheeran, P.; Hukkelberg, S. The role of self-identity in the theory of planned behavior: A meta-analysis. J. Appl. Soc. Psychol. 2010, 40, 1085-1105. [CrossRef]

45. Mainardes, E.W.; de Souza, I.M.; Correia, R.D. Antecedents and consequents of consumers not adopting e-commerce. J. Retail. Consum. Serv. 2020, 55, 1-9. [CrossRef]

46. Ajzen, I. The theory of planned behavior. Organ. Behav. Hum. Decis. Process 1991, 50, 179-211. [CrossRef]

47. Fishbein, M.; Ajzen, I. Predicting and Changing Behavior: The Reasoned Action Approach; Taylor \& Francis: New York, NY, USA, 2010.

48. Henning, V.; Hennig-Thurau, T.; Feiereisen, S. Giving the Expectancy-Value model a heart. Psychol. Mark. 2012, 29, 765-781. [CrossRef]

49. Verkuyten, M.; Yogeeswaran, K.; Adelman, L. Toleration and prejudice-reduction: Two ways of improving intergroup relations. Eur. J. Soc. Psychol. 2020, 50, 239-255. [CrossRef] 
50. Matera, C.; Imai, T.; Pinzi, S. Do you think like me? perceived concordance concerning contact and culture maintenance on international students' intentions for contact with the host-society. Int. J. Intercult. Relat. 2018, 63, 27-37. [CrossRef]

51. Üstüner, T.; Holt, D.B. Dominated consumer acculturation: The social construction of poor migrant women's consumer identity projects in a turkish squatter. J. Consum. Res. 2007, 34, 41-56. [CrossRef]

52. Rui, J.R.; Wang, H. Social network sites and international students' cross-cultural adaptation. Comput. Hum. Behav. 2015, 49, 400-411. [CrossRef]

53. Park, H.S. Relationships among attitudes and subjective norms: Testing the theory of reasoned action across cultures. Commun. Stud. 2000, 51, 162-175. [CrossRef]

54. Leung, K.; Morris, M.W. Values, schemas, and norms in the culture-behavior nexus: A situated dynamics framework. J. Int. Bus. Stud. 2015, 46, 1028-1050. [CrossRef]

55. Gunawan, D.D.; Huarng, K. Viral effects of social network and media on consumers' purchase intention. J. Bus. Res. 2015, 68, 2237-2241. [CrossRef]

56. Ashraf, A.R.; Thongpapanl, N.; Auh, S. The application of the technology acceptance model under different cultural contexts: The case of online shopping adoption. J. Int. Mark. 2014, 22, 68-93. [CrossRef]

57. Darley, W.K.; Blankson, C.; Luethge, D.J. Toward an integrated framework for online consumer behavior and decision making process: A review. Psychol. Mark. 2010, 27, 94-116. [CrossRef]

58. Makri, K.; Schlegelmilch, B.B. Time orientation and engagement with social networking sites: A cross-cultural study in austria, china and uruguay. J. Bus. Res. 2017, 80, 155-163. [CrossRef]

59. Azab, C.; Clark, T. Speak my language or look like me?-Language and ethnicity in bilingual customer service recovery. J. Bus. Res. 2017, 72, 57-68. [CrossRef]

60. Eisingerich, A.B.; Chun, H.H.; Liu, Y.; Jia, H.; Bell, S.J. Why recommend a brand face-to-face but not on facebook? how word-of-mouth on online social sites differs from traditional word-of-mouth. J. Consum. Psychol. 2015, 25, 120-128. [CrossRef]

61. Barger, V.; Peltier, J.W.; Schultz, D.E. Social media and consumer engagement: A review and research agenda. J. Res. Interact. Mark. 2016, 10, 268-287. [CrossRef]

62. Dessart, L.; Veloutsou, C.; Morgan-Thomas, A. Capturing consumer engagement: Duality, dimensionality and measurement. J. Mark. Manag. 2016, 32, 399-426. [CrossRef]

63. Allport, G.W. The Nature of Prejudice; Addison-Wesley: Reading, MA, USA, 1954.

64. Lev-On, A.; Lissitsa, S. Studying the coevolution of social distance, offline-and online contacts. Comput. Hum. Behav. 2015, 48, 448-456. [CrossRef]

65. Wojcieszak, M.; Azrout, R. I saw you in the news: Mediated and direct intergroup contact improve outgroup attitudes. J. Commun. 2016, 66, 1032-1060. [CrossRef]

66. Berry, J.W. Immigration, acculturation, and adaptation. Appl. Psychol. 1997, 46, 5-34. [CrossRef]

67. Cleveland, M.; Chang, W. Migration and materialism: The roles of ethnic identity, religiosity, and generation. J. Bus. Res. 2009, 62, 963-971. [CrossRef]

68. Laroche, M.; Yang, Z.; Kim, C.; Richard, M. How culture matters in children's purchase influence: A multi-level investigation. J. Acad. Mark. Sci. 2007, 35, 113-126. [CrossRef]

69. Pieterse, J.N. Social capital and migration beyond ethnic economies. Ethnicities 2003, 3, 29-58. [CrossRef]

70. Owusu, T.Y. The role of ghanaian immigrant associations in toronto, canada. Int. Migr. Rev. 2000, 34, 1155-1181. [CrossRef]

71. Oswald, L.R. Culture swapping: Consumption and the ethnogenesis of middle-class haitian immigrants. J. Consum. Res. 1999, 25, 303-318. [CrossRef]

72. Berry, J.W. A psychology of immigration. J. Soc. ISS 2001, 57, 615-631. [CrossRef]

73. Reichelt, J.; Sievert, J.; Jacob, F. How credibility affects eWOM reading: The influences of expertise, trustworthiness, and similarity on utilitarian and social functions. J. Mark. Commun. 2014, 20, 65-81. [CrossRef]

74. Dato-on, M.C.; Burns, D.J.; Manolis, C.; Hanvanich, S. Cultural assimilation and its effects on consumption behaviors: An examination of shopping behaviors and preferences of US hispanic immigrants. J. Shopp. Cent. Res. 2007, 13, 107-138.

75. Segev, S.; Wang, W.; Fernandes, J. The effects of ad-context congruency on responses to advertising in blogs: Exploring the role of issue involvement. Int. J. Advert. 2014, 33, 17-36. [CrossRef]

76. Quester, P.G.; Karunaratna, A.; Chong, I. Australian chinese consumers: Does acculturation affect consumer decision making? J. Int. Consum. Mark. 2001, 13, 7-28. [CrossRef]

77. Lee, E.; Fairhurst, A.; Dillard, S. Usefulness of ethnicity in international consumer marketing. J. Int. Consum. Mark. 2002, 14, 25-48. [CrossRef]

78. Wang, X.; Yu, C.; Wei, Y. Social media peer communication and impacts on purchase intentions: A consumer socialization framework. J. Interact. Mark. 2012, 26, 198-208. [CrossRef]

79. Perloff, R.M.; Bonder, B.; Ray, G.B.; Ray, E.B.; Siminoff, L.A. Doctor-patient communication, cultural competence, and minority health: Theoretical and empirical perspectives. Am. Behav. Sci. 2006, 49, 835-852. [CrossRef]

80. Paternotte, E.; van Dulmen, S.; van der Lee, N.; Scherpbier, A.J.; Scheele, F. Factors influencing intercultural doctor-patient communication: A realist review. Patient Educ. Couns. 2015, 98, 420-445. [CrossRef]

81. Stephan, W.G. Intergroup anxiety: Theory, research, and practice. Personal. Soc. Psychol. Rev. 2014, 18, 239-255. [CrossRef] 
82. Eleta, I.; Golbeck, J. Multilingual use of twitter: Social networks at the language frontier. Comput. Hum. Behav. 2014, 41, 424-432. [CrossRef]

83. La Ferle, C.; Lee, W. Can english language media connect with ethnic audiences? ethnic minorities' media use and representation perceptions. J. Advert. Res. 2005, 45, 140-153. [CrossRef]

84. Alam, K.; Imran, S. The digital divide and social inclusion among refugee migrants: A case in regional australia. Inf. Technol. People 2015, 28, 344-365. [CrossRef]

85. Yu, B.; Shen, H. Predicting roles of linguistic confidence, integrative motivation and second language proficiency on cross-cultural adaptation. Int. J. Intercult. Relat. 2012, 36, 72-82. [CrossRef]

86. Peltokorpi, V.; Pudelko, M. When more is not better: A curvilinear relationship between foreign language proficiency and social categorization. J. Int. Bus. Stud. 2020, 1-27. [CrossRef]

87. Tang, C.; Guo, L. Digging for gold with a simple tool: Validating text mining in studying electronic word-of-mouth (eWOM) communication. Mark. Lett. 2015, 26, 67-80. [CrossRef]

88. Rossmann, A.; Rossmann, A.; Ranjan, K.R.; Ranjan, K.R.; Sugathan, P.; Sugathan, P. Drivers of user engagement in eWoM communication. J. Serv. Mark. 2016, 30, 541-553. [CrossRef]

89. Glass, C.R.; Westmont, C.M. Comparative effects of belongingness on the academic success and cross-cultural interactions of domestic and international students. Int. J. Intercult. Relat. 2014, 38, 106-119. [CrossRef]

90. Ng, S.I.; Lee, J.A.; Soutar, G.N. Are hofstede's and schwartz's value frameworks congruent? Int. Mark. Rev. 2007, $24,164-180$.

91. Triandis, H.C. Culture and conflict. Int. J. Psychol. 2000, 35, 145-152. [CrossRef]

92. Mahfud, Y.; Badea, C.; Verkuyten, M.; Reynolds, K. Multiculturalism and attitudes toward immigrants: The impact of perceived cultural distance. J. Cross-Cult. Psychol. 2018, 49, 945-958. [CrossRef]

93. Guan, Y.; Verkuyten, M.; Fung, H.H.; Bond, M.H.; Chen, S.X.; Chan, C.C. Out-group value incongruence and intergroup attitude: The roles of common identity and multiculturalism. Int. J. Intercult. Relat. 2011, 35, 377-385. [CrossRef]

94. Wimmer, A.; Soehl, T. Blocked acculturation: Cultural heterodoxy among europe's immigrants. Am. J. Sociol. 2014, 120, 146-186. [CrossRef]

95. Shalev, M.; Lazarus, A. Horizontal inequality in israel's welfare state: Do arab citizens receive fewer transfer payments? In Socioeconomic Inequality in Israel; Khattab, N., Miaari, S., Stier, H., Eds.; Palgrave Macmillan US: New York, NY, USA, 2016.

96. Hino, H. Shopping at different food retail formats: Understanding cross-shopping behavior through retail format selective use patterns. Eur. J. Mark. 2014, 48, 674-698. [CrossRef]

97. Thompson, S. Sampling; John Wiley \& Sons: Somerset, NJ, USA, 2012.

98. Craig, C.S.; Douglas, S.P. International Marketing Research; Wiley: New York, NY, USA, 2005.

99. Hui, C.H.; Triandis, H.C. Measurement in cross-cultural psychology: A review and comparison of strategies. J. Cross-Cult. Psychol. 1985, 16, 131-152. [CrossRef]

100. Schober, M.F. The future of face-to-face interviewing. Qual. Assur. Educ. 2018, 26, 290-302. [CrossRef]

101. Stiegler, A.; Biedinger, N. Interviewer skills and training. In GESIS Survey Guidelines; GESIS-Leibniz Institute for the Social Sciences: Mannheim, Germany, 2016.

102. Groves, R.M.; Fowler, F.J.; Couper, M.P.; Lepkowski, J.M.; Singer, E.; Tourangeau, R. Survey Methodology; Wiley: Hoboken, NJ, USA, 2011.

103. Loosveldt, G. Face-to-face interviews. In International Handbook of Survey Methodology; de Leeuw, E.D., Hox, J.J., Dillman, D.A., Eds.; Lawrence Erlbaum: New York, NY, USA, 2008.

104. Lensvelt-Mulders, G. Surveying sensitive topics. In International Handbook of Survey Methodology; de Leeuw, E.D., Hox, J.J., Dillman, D.A., Eds.; Lawrence Erlbaum: New York, NY, USA, 2008.

105. Gvili, Y.; Levy, S. Antecedents of attitudes toward eWOM communication: Differences across channels. Internet Res. 2016, 26, 1030-1051. [CrossRef]

106. Fu, J.; Ju, P.; Hsu, C. Understanding why consumers engage in electronic word-of-mouth communication: Perspectives from theory of planned behavior and justice theory. Electron. Commer. Res. Appl. 2015, 14, 616-630. [CrossRef]

107. Cuellar, I.; Arnold, B.; Maldonado, R. Acculturation rating scale for mexican americans-II: A revision of the original ARSMA scale. Hisp. J. Behav. Sci. 1995, 17, 275-304. [CrossRef]

108. Chiu, C.; Hsu, M.; Wang, E.T. Understanding knowledge sharing in virtual communities: An integration of social capital and social cognitive theories. Decis. Support Syst. 2006, 42, 1872-1888. [CrossRef]

109. Sheldon, P Host communication competence and locus of control of international students in the united states. J. Intercult. Commun. 2010, 24.

110. Demes, K.A.; Geeraert, N. Measures matter: Scales for adaptation, cultural distance, and acculturation orientation revisited. J. Cross-Cult. Psychol. 2014, 45, 91-109. [CrossRef]

111. Pollay, R.W.; Mittal, B. Here's the beef: Factors, determinants, and segments in consumer criticism of advertising. J. Mark. 1993, 57, 99-114. [CrossRef]

112. Podsakoff, P.M.; MacKenzie, S.B.; Lee, J.; Podsakoff, N.P. Common method biases in behavioral research: A critical review of the literature and recommended remedies. J. Appl. Psychol. 2003, 88, 879. [CrossRef]

113. MacKenzie, S.B.; Podsakoff, P.M. Common method bias in marketing: Causes, mechanisms, and procedural remedies. J. Retail. 2012, 88, 542-555. [CrossRef] 
114. Podsakoff, P.M.; Organ, D.W. Self-reports in organizational research: Problems and prospects. J. Manag. 1986, 12, 531-544. [CrossRef]

115. Bagozzi, R.P.; Edwards, J.R. A general approach for representing constructs in organizational research. Organ. Res. Methods 1998, 1, 45-87. [CrossRef]

116. Henseler, J. Partial least squares path modeling. In Advanced Methods for Modeling Markets: International Series in Quantitative Marketing; Leeflang, P., Wieringa, J., Bijmolt, T., Pauwels, K., Eds.; Springer: New York, NY, USA, 2017.

117. Henseler, J.; Hubona, G.; Ray, P.A. Using PLS path modeling in new technology research: Updated guidelines. Ind. Manag. Data Syst. 2016, 116, 2-20. [CrossRef]

118. Latan, H.; Jabbour, C.J.C.; de Sousa Jabbour, A.B.L. Ethical awareness, ethical judgment and whistleblowing: A moderated mediation analysis. J. Bus. Ethics 2019, 155, 289-304. [CrossRef]

119. Chin, W.W.; Marcolin, B.L.; Newsted, P.R. A partial least squares latent variable modeling approach for measuring interaction effects: Results from a monte carlo simulation study and an electronic-mail emotion/adoption study. Inf. Syst. Res. 2003, 14, 189-217. [CrossRef]

120. Fornell, C.; Larcker, D.F. Evaluating structural equation models with unobservable variables and measurement error. J. Market. Res. 1981, 18, 39-50. [CrossRef]

121. Henseler, J.; Ringle, C.M.; Sarstedt, M. A new criterion for assessing discriminant validity in variance-based structural equation modeling. J. Acad. Mark. Sci. 2015, 43, 115-135. [CrossRef]

122. Hair, J.F.; Hult, G.T.M.; Ringle, C.; Sarstedt, M. A Primer on Partial Least Squares Structural Equation Modeling (PLS-SEM); SAGE Publications: Thousand Oaks, CA, USA, 2016.

123. Hair, J.F.; Wolfinbarger, C.M.; Money, A.; Samouel, P.; Page, M. Essentials of Business Research Methods, 3rd ed.; ME Sharpe: Armonk, NY, USA, 2015.

124. Kock, N. WarpPLS 5.0 User Manual; ScriptWarp Systems: Laredo, TX, USA, 2015.

125. Charmaraman, L.; Chan, H.B.; Chen, S.; Richer, A.; Ramanudom, B. Asian american social media use: From cyber dependence and cyber harassment to saving face. Asian Am. J. Psychol. 2018, 9, 72-86. [CrossRef]

126. Oetzel, J.G.; Ting-Toomey, S. Face concerns in interpersonal conflict: A cross-cultural empirical test of the face negotiation theory. Commun. Res. 2003, 30, 599-624. [CrossRef]

127. Emerson, R.M. Social exchange theory. Annu. Rev. Sociol. 1976, 2, 335-362. [CrossRef]

128. Chu, S.; Lien, C.; Cao, Y. Electronic word-of-mouth (eWOM) on WeChat: Examining the influence of sense of belonging, need for self-enhancement, and consumer engagement on chinese travellers' eWOM. Int. J. Advert. 2019, 38, 26-49. [CrossRef]

129. Shapiro, L.A.S.; Margolin, G. Growing up wired: Social networking sites and adolescent psychosocial development. Clin. Child. Fam. Psychol. Rev. 2014, 17, 1-18. [CrossRef]

130. Lin, J.; Li, L.; Yan, Y.; Turel, O. Understanding chinese consumer engagement in social commerce: The roles of social support and swift guanxi. Internet Res. 2018, 28, 2-22. [CrossRef]

131. Kalmijn, M.; Van Tubergen, F. Ethnic intermarriage in the netherlands: Confirmations and refutations of accepted insights. Eur. J. Popul. /Rev. Eur. Demogr. 2006, 22, 371-397. [CrossRef]

132. Fishbein, M.; Ajzen, I. Belief, Attitude, Intention, and Behavior: An Introduction to Theory and Research; Addison-Wesley Publishing Company: Reading, MA, USA, 1975.

133. Money, R.B.; Gilly, M.C.; Graham, J.L. Explorations of national culture and word-of-mouth referral behavior in the purchase of industrial services in the united states and japan. J. Mark. 1998, 62, 76-87. [CrossRef]

134. Chu, S.; Choi, S.M. Electronic word-of-mouth in social networking sites: A cross-cultural study of the united states and china. J. Glob. Mark. 2011, 24, 263-281. [CrossRef]

135. Christodoulides, G.; Michaelidou, N.; Argyriou, E. Cross-national differences in e-WOM influence. Eur. J. Mark. 2012, 46, 1689-1707. [CrossRef]

136. Gvili, Y.; Levy, S. Consumer engagement in sharing brand-related information on social commerce: The roles of culture and experience. J. Mark. Commun. 2019, 27, 53-68. [CrossRef]

137. Luo, C.; Wu, J.; Shi, Y.; Xu, Y. The effects of individualism-collectivism cultural orientation on eWOM information. Int. J. Inf. Manag. 2014, 34, 446-456. [CrossRef]

138. Voss, K.E.; Spangenberg, E.R.; Grohmann, B. Measuring the hedonic and utilitarian dimensions of consumer attitude. J. Mark. Res. 2003, 40, 310-320. [CrossRef]

139. Calder, B.J.; Isaac, M.S.; Malthouse, E.C. How to capture consumer experiences: A context-specific approach to measuring engagement. J. Advert. Res. 2016, 56, 39-52. [CrossRef]

140. Voorveld, H.A.; van Noort, G.; Muntinga, D.G.; Bronner, F. Engagement with social media and social media advertising: The differentiating role of platform type. J. Advert. 2018, 47, 38-54. [CrossRef]

141. Barykin, S.Y.; Kapustina, I.V.; Sergeev, S.M.; Kalinina, O.V.; Vilken, V.V.; de la Poza, E.; Putikhin, Y.Y.; Volkova, L.V. Developing the physical distribution digital twin model within the trade network. Acad. Strateg. Manag. J. 2021, 20, 1-18.

142. Barykin, S.Y.; Bochkarev, A.A.; Dobronravin, E.; Sergeev, S.M. The place and role of digital twin in supply chain management. Acad. Strateg. Manag. J. 2021, 20,1-19.

143. Dospinescu, O.; Dospinescu, N.; Bostan, I. Determinants of e-commerce satisfaction: A comparative study between romania and moldova. Kybernetes 2021, in press. [CrossRef] 
144. Simonson, I.; Rosen, E. What marketers misunderstand about online reviews. Harv. Bus. Rev. 2014, 92, $23-25$.

145. Supermarkets Aren't Effectively Marketing to US-Born Hispanics, Report Finds; c2018. Available online: https://www.fooddive. $\mathrm{com} /$ news/supermarkets-arent-effectively-marketing-to-us-born-hispanics-report-find/524031/ (accessed on 7 October 2018).

146. Rosenberg, N.; Daviglus, M.L.; DeVon, H.A.; Park, C.G.; Eldeirawi, K. The association between parity and inflammation among mexican-american women of reproductive age varies by acculturation level: Results of the national health and nutrition examination survey (1999-2006). Womens Health Issues 2017, 27, 485-492. [CrossRef]

147. Lazer, D. Social sciences. the rise of the social algorithm. Science 2015, 348, 1090-1091. [CrossRef] [PubMed]

148. Bakshy, E.; Messing, S.; Adamic, L.A. Political science. exposure to ideologically diverse news and opinion on facebook. Science 2015, 348, 1130-1132. [CrossRef]

149. McPherson, M.; Smith-Lovin, L.; Cook, J.M. Birds of a feather: Homophily in social networks. Annu. Rev. Sociol. 2001, 27, 415-444. [CrossRef]

150. Peñaloza, L. Ethnic marketing practice and research at the intersection of market and social development: A macro study of the past and present, with a look to the future. J. Bus. Res. 2018, 82, 273-280. [CrossRef]

151. Pookulangara, S.; Koesler, K. Cultural influence on consumers' usage of social networks and its' impact on online purchase intentions. J. Retail. Consum. Serv. 2011, 18, 348-354. [CrossRef]

152. Pavlou, P.A.; Chai, L. What drives electronic commerce across cultures? across-cultural empirical investigation of the theory of planned behavior. J. Electron. Commer. Res. 2002, 3, 240-253.

153. Sterling, B.A.; Christensen, G.L.; Williams, J.D. Rejected, shackled, and alone: The impact of systemic restricted choice on minority consumers' construction of self. J. Consum. Res. 2014, 41, 451-474.

154. Bartikowski, B.; Laroche, M.; Jamal, A.; Yang, Z. The type-of-internet-access digital divide and the well-being of ethnic minority and majority consumers: A multi-country investigation. J. Bus. Res. 2018, 82, 373-380. [CrossRef] 